\title{
Disaster risk reduction: a decision-making support tool based on the morphological analysis
}

\section{Nieves Lantada ${ }^{a}$, Martha Liliana Carreño ${ }^{b}$, Nayive Jaramillo ${ }^{c}$}

\footnotetext{
${ }^{a}$ Division of Geotechnical Engineering and Geosciences, Department of Civil and Environmental Engineering, Universitat Politècnica de Catalunya, Jordi Girona1-3, Building D2, Campus Nord UPC, 08034 Barcelona, Spain.

${ }^{\mathrm{b}}$ Centre Internacional de Mètodes Numèrics en l'Enginyeria (CIMNE), Departament de Resistència de Materials i Estructures a l'Enginyeria (RMEE), Department of Civil and Environmental Engineering, Universitat Politècnica de Catalunya, JordiGirona1-3, Building C1, Campus Nord UPC, 08034 Barcelona, Spain.

${ }^{\mathrm{c}}$ Department of Civil Engineering, Universidad EAFIT (Escuela de Administración, Finanzas e Instituto Tecnológico), Medellín, Colombia.
}

\begin{abstract}
Risk management due to natural hazards is a multidimensional and complex problem since it requires the knowledge and experience of several disciplines. The effectiveness of risk management can be analyzed, inviting to the action through weakness identification of the urban area. This article proposes a methodology based on the morphological analysis to support the decision-making on disaster risk management, taking as a starting point the results of a holistic evaluation of the seismic risk. The results of the holistic evaluation of risk are achieved aggravating the physical risk using the contextual conditions, such as the socioeconomic fragility and the lack of resilience. In consequence, the risk mitigation can be performed through the reduction of the potential damage and consequences involved; and the improvement of social conditions.

The proposed methodology allows prioritizing the risk reduction strategies according to $i$ ) performance level of component indicators involved into the Disaster Risk Management index, $D R M i$; ii) physical risk factors dependent from the potential damages, and iii) aggravating factors involved in the aggravating coefficient. Moreover, it involves 35 strategies to reduce the physical risk and the aggravating social conditions of the urban area.

The proposed methodology has been applied to the city of Mérida (Venezuela), located within an area of high seismic activity. The performance level of the indicators involved in the $D R M i$ was evaluated by a survey to local experts. As a result, eleven strategies have been identified to reduce the potential damage and to improve the social conditions of this city.
\end{abstract}

Keywords: morphological analysis; Disaster Risk Management; decision-making support tool; risk reduction; DRM strategies 


\section{Introduction}

Risk management due to a natural hazard is a multidimensional and complex problem since it requires the knowledge and experience of several disciplines (engineering, geology, seismology, geosciences, hydrology, and social sciences, among others). Moreover, at a global level, the risk is usually assessed in physical terms $[1,2,3,4,5,6]$, the social vulnerability can be difficult to quantify, but it is necessary to assess it at different levels (local, regional and national level) and involving several characteristics of the studied area $[7,8,9,10,11,12,13$, among others].

Seismic risk is usually evaluated through the estimation of the potential direct effects; there are several methodologies around the world focused on the calculation of the potential damages, destroyed area, dead and injured people, homeless and jobless people, debris and so on $[1,2,3,4,6,14]$. The mentioned estimations are recognized as a direct effect of the seismic events and are calculated based on the evaluation of the destroyed area and the primary use of the exposed assets. Other studies are focused on the secondary effects of the seismic and other catastrophic events, and they are mainly focused on different sectors of the society $[15,16]$, the local economy $[17,18]$ or activity level of companies, which in many cases depends on the resilience and functionality of the restored lifelines [19,20] and essential buildings [21].

Some methodologies evaluate the disaster risk from a comprehensive (or holistic) approach taking into account aspects of the social context like economic and social development absence, deficiencies of institutional management, and lack of capacity for response and recovery from a dangerous event $[5,9,22,23,24,25,26]$. These methodologies allow assessing the disaster risk from a holistic perspective and identify the characteristics of the social context and physical vulnerabilities that can be improved to reduce the risk level.

The disaster risk assessment is a fundamental part of the disaster risk management, it is a pillar for an informed decision-making process. The efforts on disaster risk management can be challenging to evaluate due to they remain invisible until a catastrophic event occurs. The attempt to measure risk management, when faced with natural phenomena, is a significant challenge from the conceptual, scientific, technical, and numerical perspectives. Indicators must be transparent, robust, representative, and easily understood by public policymakers at national, subnational, and urban level [27]. 
The evaluation of risk management through the definition of performance benchmarks, establish performance targets to improve management effectiveness. This kind of assessment was developed [27] and applied by the Inter-American Development Bank to the monitoring of the disaster risk management performance in the counties of the Latin-American and Caribbean Region.

Disaster risk reduction (DRR) policies are necessary to prevent and reduce disaster risk in urban areas, despite continuing limitations and difficulty in its implementation [28]. Therefore, it is necessary to prioritize the actions and strategies to be implemented based on the available information. There are several methodologies that can help in this decision-making process. On the one hand, the methods such as the spatial decision support systems (SDSSs), the structured decision making (SDM), the multi-criteria decision analysis (MCDA) or the costbenefit Analysis (CBA) [29,30], among others, are fundamental to help risk-managers make better decisions. On the other hand, the General Morphological Analysis (GMA) [31] is a problem-solving technique to helping decision making in wicked problems and social disorders. The GMA has been applied extensively in different areas, but very few integrate stakeholders of public sector in decision-making process and cover all phases of a decision-making process [32].

This article proposes a decision support tool based on the morphological analysis method involving the holistic evaluation of the seismic risk [5] and the evaluation of the disaster risk management performance [27].

\section{The starting point methodologies}

\subsection{Holistic evaluation of risk}

In the holistic evaluation of risk using indices, risk results are achieved aggravating the physical risk using the contextual conditions, such as the socio-economic fragility and the lack of resilience $[5,9,25]$. Input data about these conditions at the urban level are necessary to apply the method. This approach contributes to the effectiveness of risk management, inviting to the action through the identification of weaknesses of the urban center.

The socio-economic fragility and the lack of resilience are described by a set of indicators (related to indirect or intangible effects) that aggravate the physical risk (potential 
direct effects). Thus, the total risk depends on the direct effect or physical risk, and the indirect effects expressed as a factor of the direct effect. Therefore, the total risk is expressed as follows:

$$
R_{T}=R_{P h}(1+F)
$$

where $R_{T}$ is the total risk index, $R_{P h}$ is the physical risk index, and $F$ is the aggravating coefficient. This coefficient depends on the weighted sum of a set of aggravating factors related to the socio-economic fragility, $F_{S F i}$, and the lack of resilience of the exposed context, $F_{L R j}$ (see Equation (2)).

$$
F=\sum_{i=1}^{m} w_{S F i} \times F_{S F i}+\sum_{j=1}^{n} w_{L R j} * F_{L R j}
$$

where $w_{S F i}$ and $w_{L R j}$ are the weights of each factor of social fragility and lack of resilience, respectively.

The aggravating factors are based on standard indicators, easy to collect, measuring social aspects, which can make the situation worse in the case that a seismic event occurs. The social indicators can be selected from the used by urban observatories of United Nations and other social researchers; such as indicators of the Habitat Agenda (1996) [33], Istanbul+5 (2001) [34], Millennium Development Goals [35] and Carreño et al. [5,22,23]. The aggravating factors $F_{S F i}$ and $F_{L R j}$ are calculated using transformation functions. The descriptors used in this evaluation have different nature and units; the transformation functions standardize the gross values of the descriptors, transforming them into commensurable factors, taking values between 0 and $1[5,25]$.

The weights $w_{S F i}$ and $w_{L R j}$ represent the relative importance of each factor and are calculated using the Analytic Hierarchy Process (AHP), which is used to derive ratio scales from both discrete and continuous paired comparisons [5,36,37].

The physical risk, $R_{P h}$, is evaluated in the same way, by using the following equation:

$$
R_{P h}=\sum_{k=1}^{p} w_{R P h k} * F_{R P h k}
$$

This holistic seismic risk assessment improves prior methodologies because their results are standard and easy to interpret [25].

\subsection{Disaster risk management index, $D R M_{i}$}


An Integrated Disaster Risk Management involves the disaster risk reduction and the adaptation to climate change considering economic, social, and environmental issues. These require a suitable strategy for vulnerability reduction and resilience improvement [38]. The Disaster Risk Management index, $D R M i$, is an innovative indicator for the measurement of the performance and likely effectiveness of risk management, developed in the framework of the Program of Indicators for Disaster Risk and Risk Management in the Americas of the InterAmerican Development Bank [27].

The $D R M i$ provides a quantitative measure of management based on predefined qualitative targets or benchmarks that risk management efforts should aim to achieve. These reflect the organizational, development, capacity and institutional action taken to reduce vulnerability and losses, to prepare for a crisis, and to recover efficiently. The index is constructed by quantifying four public policies:

- Risk identification index, $R M I_{R I}$, comprises the evaluation of individual and social perception, risk knowledge and understanding and the appropriate assessment of risk.

- Risk reduction index, $R M I_{R R}$, the implementation of corrective and prospective prevention and mitigation actions and measures to reduce vulnerability.

- Disaster management index, $R M I_{D M}$, comprises the advances in preparedness, response, and recovery.

- Governance and financial protection, $R M I_{F P}$, measures the degree of institutionalization and risk transfer strategies to financial protection.

The $D R M i$ is defined as the average of the four composite indicators (Equation 4).

$$
D R M i=\operatorname{avg}\left(R M I_{R I}, R M I_{R R}, R M I_{D M}, R M I_{F P}\right)
$$

Six indicators are used for each public policy (Figure 1). Their evaluation is based on five performance levels (low, incipient, significant, outstanding, and optimal) that correspond to a range from 1 (low) to 5 (optimal) [27,37]. This methodological approach permits the use of each reference level simultaneously as a performance objective or target and allows for comparison and identification of results or achievements. Government efforts at formulating, implementing, and evaluating policies should bear these performance targets in mind. Such linguistic values are the same as a fuzzy set that has a membership function of the bell or sigmoidal (at the extremes) type, as can be seen in Figure 2. 


\begin{tabular}{|l|l|l|}
\hline$R I 1$ & Systematic disaster and loss inventory & $w_{R I}$ \\
\hline$R I 2$ & Hazard monitoring and forecasting & $w_{R I}$ \\
\hline$R I 3$ & Hazard evaluation and mapping & $w_{R I}$ \\
\hline$R I 4$ & Vulnerability and risk assessment & $w_{R I}$ \\
\hline$R I 5$ & Public information and community participation & $w_{R I}$ \\
\hline$R I 6$ & Training and education on risk management & $w_{R I}$ \\
\hline
\end{tabular}

\begin{tabular}{|l|l|l|}
\hline$R R 1$ & Risk consideration in land use and urban planning & $w_{R R 1}$ \\
\hline$R R 2$ & Hydrographical basin intervention and environmental protection & $w_{R R 2}$ \\
\hline$R R 3$ & Implementation of hazard-event control and protection techniques & $w_{R R 3}$ \\
\hline$R R 4$ & Housing improvement and human settlement relocation from prone-areas & $w_{R R 4}$ \\
\hline$R R 5$ & Updating and enforcement of safety standards and construction codes & $w_{R R 5}$ \\
\hline$R R 6$ & Reinforcement and retrofitting of public and private assets & $w_{R R 6}$ \\
\hline
\end{tabular}

\begin{tabular}{|l|l|l|}
\hline$D M 1$ & Organization and coordination of emergency operations & $w_{D M}$ \\
\hline$D M 2$ & Emergency response planning and implementation of warning systems & $w_{D M}$ \\
\hline$D M 3$ & The endowment of equipment, tools, and infrastructure & $w_{D M}$ \\
\hline$D M 4$ & Simulation, updating, and test of inter-institutional response & $w_{D M}$ \\
\hline$D M 5$ & Community preparedness and training & $w_{D M}$ \\
\hline$D M 6$ & Rehabilitation and reconstruction planning & $w_{D M}$ \\
\hline
\end{tabular}

\begin{tabular}{|l|l|l|}
\hline$F P 1$ & Inter-institutional, multi-sectoral and decentralizing organization & $w_{F P 1}$ \\
\hline$F P 2$ & Reserve funds for institutional strengthening & $w_{F P 2}$ \\
\hline$F P 3$ & Budget allocation and mobilization & $w_{F P 3}$ \\
\hline$F P 4$ & Implementation of social safety nets and funds response & $w_{F P 4}$ \\
\hline$F P 5$ & Insurance coverage and loss transfer strategies of public assets & $w_{F P 5}$ \\
\hline$F P 6$ & Housing and private sector insurance and reinsurance coverage & $w_{F P 6}$ \\
\hline
\end{tabular}

Figure 1. Component indicators for DRMi [27]

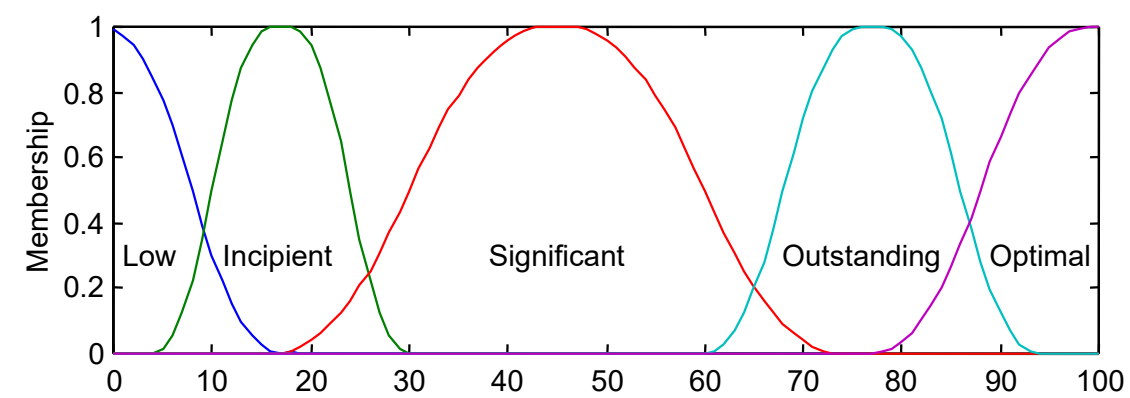

Figure 2. Functions that represents the performance management levels $[27,37]$

Once performance levels of each indicator have been evaluated, the value of each component of the $D R M i$ is determined through a non-linear aggregation model based on fuzzy 
logic. The value of each component ranges between 0 and 100. The evaluation is based on opinions from local experts who provide qualifications of the indicators and assign relative importance between them for each public policy according to their experience and knowledge. This relative importance is processed using the Analytic Hierarchy Process (AHP) to assign weights [36]. Weights assigned sum 1 and they are used to give height to the membership functions of the fuzzy sets corresponding to the qualifications made.

Qualification for each public policy is the result of the union of the weighted fuzzy sets. The risk management index value $R M I_{p}$ is obtained from the defuzzification of this membership function (Equation 5), using the method of the centroid of the area, COA.

$R M I_{p}=\left[\max \left(w_{1} \times \mu_{C}\left(C_{1}\right), \ldots, w_{N} \times \mu_{C}\left(C_{N}\right)\right)\right]_{\text {centroid }}$

Where $w_{1}$ to $w_{N}$ are the weights of the indicators of Figure $1, \mu_{C}\left(C_{1}\right)$ to $\mu_{C}\left(C_{N}\right)$ are the membership functions of the estimates made for each indicator. The value of each composed element is between 0 and 100 , where 0 is the minimum performance level, and 100 is the maximum level. Total $D R M i$ is the average of the four composed indicators that admit each public policy.

Nowadays, the international community recognizes that disaster risk mitigation and reduction actions shall be involved in the policies, plans, and programs for sustainable development. It is necessary to improve the capacity to reduce risk as it is recommended by several international organizations, projects, and governments $[2,3,4,14,39,40,41,42,43$ among others].

This article proposes a methodology to support the decision-making on disaster risk management in an urban area exposed to natural hazards. This methodology is based on a morphological analysis to support the formulation of action plans for disaster risk mitigation taking as a starting point a holistic evaluation of risk. Such mitigation can be performed through: a) the reduction of the potential damage and consequences involved; and $b$ ) the improvement of social conditions. This proposed methodology allows prioritizing the risk reduction strategies to implement in an urban area according to $i$ ) the performance levels of the component indicators involved in the $D R M i$, ii) the physical risk factors dependent from the potential damages, and iii) the aggravating factors involved in the aggravating coefficient. 


\subsection{Morphological Analysis}

General morphological analysis (GMA) is a method for systematically structuring and analyzing the total set of relationships contained in multi-dimensional, non-quantifiable problem complexes $[44,45]$. The GMA examines all possible relationships between the various social, political, and organizational dimensions of a complex problem. In 1995, advanced computer support for GMA (MA/Casper, Computer Aided Scenario and Problem Evaluation Routine) was developed at the Swedish National Defense Research Agency (FOI) [46]. This method made it possible to create non-quantified inference models, which significantly extend GMA's functionality and areas of application [31,32,44,46,47]. According to Ritchey [44], one of the advantages of GMA is that there are no formal constraints to mixing and comparing such different types of issues. On the contrary, if we are really to get to the bottom of the policy problem, we must treat all relevant issues together.

The GMA consist of a series of iterative steps that correspond to the analysis-synthesis process [46]:

Analysis Phase: The dimensions of the problem complex to be investigated are defined regarding variables and variables values through two steps:

Step 1: Identify the dimensions, parameters or variables that best define the problem complex or scenario. Each variable is represented in a column of the morphological field (Figure 3, first row in grey).

Step 2: For each variable, define the range of relevant, discrete values or conditions, which the variable can express. The variable and variable-condition matrix is the morphological field - an n-dimensional coordinate system that implicitly contains an outcome space for the problem complex thus defined. Thus, a morphological field is constructed by setting the parameters against each other to create an $n$-dimensional configuration space (Figure 3, all rows except the first one). This step also concludes the analysis phase.

\begin{tabular}{|l|l|l|l|l|l|}
\hline Parameter A & Parameter B & Parameter C & Parameter D & Parameter E & Parameter F \\
\hline Condition A1 & Condition B1 & Condition C1 & Condition D1 & Condition E1 & Condition F1 \\
\hline Condition A2 & Condition B2 & Condition C2 & Condition D2 & Condition E2 & Condition F2 \\
\hline Condition A3 & Condition B3 & Condition C3 & Condition D3 & Condition E3 & \\
\hline Condition A4 & & Condition C4 & & Condition E4 & \\
\hline Condition A5 & & Condition C5 & & Condition E5 & \\
\hline & & & & Condition E6 & \\
\hline
\end{tabular}

Figure 3. 6-parameter morphological field [49].

Synthesis Phase: Link variables and synthesize an outcome space. 
Step 3: Assess the internal consistency of all pairs of variable conditions, identifying all inconsistent or contradictory pairs. This is an important step both for verifying the quality of the morphological field (vaguely defined concepts are immediately revealed in this process), and preparing for its reduction. Use a Cross-Consistency Matrix (CCM) (Figure 4) to assess the internal consistency by considering only pairs of variable values that are internally consistent (internal consistency evaluates the logical, rather than the causal relationship between two variables).

A particular configuration (the darkened cells in the matrix of Figure 3) within this space contains one "value" from each of the parameters and thus marks out a particular state of, or possible formal solution to, the problem complex. The internal relationships between the field parameters are evaluated and "reduce" the field by weeding out configurations that contain mutually contradictory conditions. In this way, a preliminary outcome or solution space is created within the morphological field without having first to consider all of the configurations as such. This is achieved by the process of cross-consistency assessment. All of the parameter values in the morphological field are compared with one another, pair-wise, in the manner of a cross-impact matrix (Figure 4). As each pair of conditions is examined, a judgment is made as to whether - or to what extent - the pair can coexist, i.e., represent a consistent relationship. Note that there is no reference here to direction or causality, but only to mutual consistency [48].

The Cross-Consistency Matrix (CCM) is formed with the resulting pairs of all the conditions of each parameter with each other condition of all the other parameters. A box of parameters (BP) is composed of all conditions matched between two parameters, with crossreferences in the form of a two-dimensional typology. Figure 4 shows the consistency matrix for the reference morphological field given in Figure 3, which has fifteen boxes of parameters, see the alternating shaded box or not. 


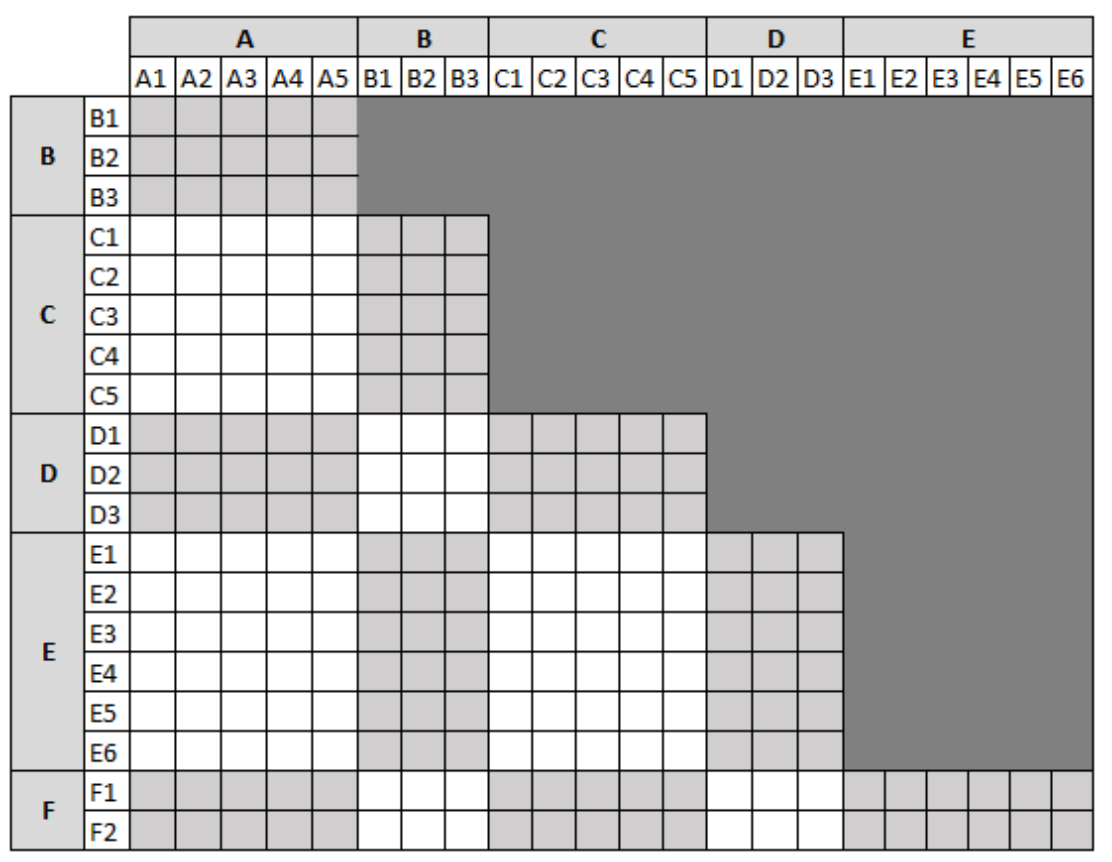

Figure 4. The Cross-Consistency Matrix (CCM) for the morphological field in Figure 3 [49].

Once the CCM cells of the morphological model to be analyzed have been defined, the crossconsistency assessment process is applied, that means the relationship between the parameter blocks is evaluated using evaluation keys [44,47].

All the values between factors are compared with one another pair-wise and checked for internal consistency by asking the question: Can these two conditions coexist in the context of the problem complex? If the answer is yes, $a$ " "-" is assigned to the combination. If the answer is $n o$, an " $\mathrm{X}$ " is assigned to the combination. Alternatively, if the answer is maybe, a " $K$ " is assigned. Depending on the problem structure, the number of configurations is reduced by $90 \%$ or more by using this technique. Consequently, the number of possible combinations becomes more manageable for an observer [47]. These answers (“-“, " $X$ ”, “ $K$ ”) are called evaluation keys.

Step 4: Synthesize an internally consistent outcome space. MA/Casper does this by running through all of the possible formal outcomes (configurations) in the morphological field (there can be many thousands or millions) and "reducing" the field by throwing out all outcomes containing internal contradictions. This leaves a "solution space".

Step 5: Iterate the process if necessary. Scrutinize the solution space and return to steps 1,2 and 3 in order to adjust variables, alternatives and consistency measures. Run steps 4 and 5 again.

The results obtained from a morphological analysis can be of great help in decision-making. Examples of several applications can be found in $[48,49,50,51]$. 


\section{Decision-making support tool for an integrated disaster risk management}

The proposed methodology is based on an adaptation of the morphological analysis to support the decision-making on disaster risk management. It should be highlighted that, the methodology proposed in this study, could be applied to any natural hazard using as parameters: the proposed actions and the possible damages to reduce. In the following sections, the different phases of that methodology are shown for the specific case of seismic hazard.

The methodology follows a holistic approach for the disaster risk analysis, assuming that it is necessary to improve the vulnerability conditions in the physical dimension to reduce the seismic risk, but also it is necessary to improve the socio-economic fragilities and resilience conditions. On this way, it is possible to reduce not only the direct effects but also to reduce the second-order effects of a seismic event. In consequence, it is proposed to perform two separated morphologic analyses, one with the purpose to analyze the physical risk reduction, and a second one to reduce the aggravating conditions related to the social fragilities and resilience of the urban center. The variables for both morphological analysis are selected based on the indicators included in the methodologies described in sections 2.1. and 2.2.

The proposed methodology identifies two types of variables, the descriptors or indicators to composed the physical risk and the aggravating conditions (section 2.1), and on the other way, the strategies to reduce them. In the analysis phase, two morphological fields are defined based on the components of the holistic evaluation of risk. The first one has the purpose of reducing the physical risk, $R_{P h}$, and the second to improve the aggravating coefficient, $F$, including a total of 35 strategies.

The Cross-Consistency Matrices (CCM) are assembled focused on the relationship between strategies versus the indicators involved in each case (equivalent to column A in Figure 4). For this reason, the proposed methodology does not include the pair-wise comparison between strategies, and the CCM are not diagonal. This means that the relationship between strategies is not analyzed.

\subsection{Strategies to reduce physical risk $\left(R_{P h}\right)$}

To reduce the physical risk index $\left(R_{P h}\right)$, as it is defined in section 2 , it is necessary to take measures to reduce the potential damage, estimated of elements exposed to hazard. 
In this methodology, the strategies to reduce physical risk correspond to the 24 component indicators involved in the DRMi (Figure 1, [27]). Those strategies or actions in an optimal level allow minimizing the physical vulnerability of the urban area and some social aspects such as risk governance. To estimate each indicator five levels of performance are used, that range from 1 (the lowest level) to 5 (the highest level): low, incipient, significant, outstanding and optimal. In this methodology, each level of reference is used as an objective of performance.

\subsubsection{Analysis Phase}

For the specific case of seismic hazard, all exposed elements which damage depends on the earthquake occurrence are considered as physical risk such as collapsed buildings area, damage to lifelines (e.g. power supply, telecommunication, other transport systems) and according to HAZUS'99 [54] human victims (dead, injured and people who become homeless). However, to maintain consistency with the application for the case of study (city of Mérida in Venezuela, section 4), the methodology shown here is limited to the elements presented for which the information is available for that city.

The following six descriptors of physical damages for an urban area have been considered in the case of seismic hazard: percentage of destroyed area $\left(X_{R P h 1}\right)$, dead people (\%) $\left(X_{R P h 2}\right)$, injured people (\%o) $\left(X_{R P h 3}\right)$, homeless (\%o) $\left(X_{R P h 4}\right)$, potential damage in the system of potable water (tears per kilometer) $\left(X_{R P h 5}\right)$, and damage for the road system (percentage affected of the road system) $\left(X_{R P h 6}\right)$. Table 1 shows the morphological field for reduction of the urban seismic risk $\left(R_{P h}\right)$. 
Table 1. Morphological field to reduce the urban seismic risk $\left(\boldsymbol{R}_{\boldsymbol{P h}}\right)$

\begin{tabular}{|c|c|c|c|c|c|c|c|c|c|}
\hline \multirow{2}{*}{\multicolumn{2}{|c|}{$\begin{array}{c}\text { DESCRIPTORS of } \\
\text { PHYSICAL DAMAGE }\end{array}$}} & \multicolumn{8}{|c|}{ STRATEGIES } \\
\hline & & \multicolumn{2}{|c|}{ Risk identification } & \multicolumn{2}{|r|}{ Risk reduction } & \multicolumn{2}{|r|}{ Disaster management } & \multicolumn{2}{|c|}{$\begin{array}{c}\text { Governance and financial } \\
\text { protection }\end{array}$} \\
\hline$X_{R P h 1}$ & $\begin{array}{l}\text { Percentage of } \\
\text { destroyed area }\end{array}$ & $R I 1$ & $\begin{array}{l}\text { Systematic } \\
\text { disaster and loss } \\
\text { inventory }\end{array}$ & $R R 1$ & $\begin{array}{l}\text { Risk consideration in } \\
\text { land use and urban } \\
\text { planning }\end{array}$ & $D M 1$ & $\begin{array}{l}\text { Organization and } \\
\text { coordination of } \\
\text { emergency operations }\end{array}$ & $F P 1$ & $\begin{array}{l}\text { Inter-institutional, } \\
\text { multi-sectoral and } \\
\text { decentralizing } \\
\text { organization }\end{array}$ \\
\hline$X_{R P h 2}$ & Dead people & $R I 2$ & $\begin{array}{l}\text { Hazard } \\
\text { monitoring and } \\
\text { forecasting }\end{array}$ & $R R 2$ & $\begin{array}{l}\text { Hydrographical basin } \\
\text { intervention and } \\
\text { environmental } \\
\text { protection }\end{array}$ & $D M 2$ & $\begin{array}{l}\text { Emergency response } \\
\text { planning and } \\
\text { implementation of } \\
\text { warning systems }\end{array}$ & $F P 2$ & $\begin{array}{l}\text { Reserve funds for } \\
\text { institutional } \\
\text { strengthening }\end{array}$ \\
\hline$X_{R P h 3}$ & Injured people & $R I 3$ & $\begin{array}{l}\text { Hazard evaluation } \\
\text { and mapping }\end{array}$ & $R R 3$ & $\begin{array}{l}\text { Implementation of } \\
\text { hazard-event control } \\
\text { and protection } \\
\text { techniques }\end{array}$ & $D M 3$ & $\begin{array}{l}\text { Endowment of } \\
\text { equipment, tool, and } \\
\text { infrastructure }\end{array}$ & FP3 & $\begin{array}{l}\text { Budget allocation and } \\
\text { mobilization }\end{array}$ \\
\hline$X_{R P h 4}$ & Homeless & RI4 & $\begin{array}{l}\text { Vulnerability and } \\
\text { risk assessment }\end{array}$ & $R R 4$ & $\begin{array}{l}\text { Housing improvement } \\
\text { and human settlement } \\
\text { relocation from prone- } \\
\text { areas }\end{array}$ & $D M 4$ & $\begin{array}{l}\text { Simulation, updating, } \\
\text { and test of inter- } \\
\text { institutional response }\end{array}$ & FP4 & $\begin{array}{l}\text { Implementation of } \\
\text { social safety nets and } \\
\text { funds response }\end{array}$ \\
\hline$X_{R P h 5}$ & $\begin{array}{l}\text { Potential } \\
\text { damage in the } \\
\text { system of } \\
\text { potable water }\end{array}$ & RI5 & $\begin{array}{l}\text { Public } \\
\text { information and } \\
\text { community } \\
\text { participation }\end{array}$ & $R R 5$ & $\begin{array}{l}\text { Updating and } \\
\text { enforcement of safety } \\
\text { standards and } \\
\text { construction codes }\end{array}$ & DM5 & $\begin{array}{l}\text { Community } \\
\text { preparedness and } \\
\text { training }\end{array}$ & FP5 & $\begin{array}{l}\text { Insurance coverage } \\
\text { and loss transfer } \\
\text { strategies of public } \\
\text { assets }\end{array}$ \\
\hline$X_{R P h 6}$ & $\begin{array}{c}\text { Damage for the } \\
\text { road system }\end{array}$ & RI6 & $\begin{array}{l}\text { Training and } \\
\text { education on risk } \\
\text { management }\end{array}$ & $R R 6$ & $\begin{array}{l}\text { Reinforcement and } \\
\text { retrofitting of public } \\
\text { and private assets }\end{array}$ & DM6 & $\begin{array}{l}\text { Rehabilitation and } \\
\text { reconstruction } \\
\text { planning }\end{array}$ & FP6 & $\begin{array}{l}\text { Housing and private } \\
\text { sector insurance and } \\
\text { reinsurance coverage }\end{array}$ \\
\hline
\end{tabular}

\subsubsection{Synthesis Phase}

Once the morphological field is defined (Table 1), the Synthesis Phase (step 3 and step 4) starts to propose risk reduction strategies for the corresponding action plans.

\section{Step 3: The Cross-Consistency Matrix (CCM) for morphological field}

The CCMs are assembled focused on the relationship between strategies versus the indicators to reduce physical damage and those to improve the aggravating factor. For this reason, the proposed methodology does not include the pair-wise comparison between strategies in Table 2 (equivalent to column A in Figure 4).

The Cross-Consistency Matrix is setting by the relationship between the six parameters $\left(X_{R P h}\right)$ using evaluation keys, that must be obtained from interview to local experts, to reduce the physical risk of seismic hazard. Table 2 shows this CCM with the 24 strategies (indicators contributing to the Disaster Risk Management index, DRMi) in the first column and the descriptors to reduce the physical damage in the first row.

The evaluation keys and their meaning are adapted for the proposed methodology as follows: The key "Y" given in Table 2 (cells in dark grey), means that the strategy influences favorably in the physical damage descriptor in other words, it improves the corresponding 
physical damage descriptor to set a low value in its contributing factor to the physical risk. The key "N" (cells in white) means that the strategy does not influence the physical damage descriptor. Finally, the key " $m$ " (cells in light grey) indicates that the strategy is unlikely to influence favorably in the descriptor.

Table 2. The Cross-Consistency Assessment (CCA) to reduce the seismic physic risk of urban areas $\left(R_{P h i}\right)$

\begin{tabular}{|c|c|c|c|c|c|c|}
\hline \multirow{2}{*}{$\begin{array}{c}\text { Strategies } \\
\text { (Column 1) }\end{array}$} & \multicolumn{5}{|c|}{ Descriptors } \\
\cline { 2 - 7 } & $X_{R P h 1}$ & $X_{R P h 2}$ & $X_{R P h 3}$ & $X_{R P h 4}$ & $X_{R P h 5}$ & $X_{R P h 6}$ \\
\hline$R I 1$ & $m$ & $m$ & $m$ & $m$ & $m$ & $m$ \\
\hline$R I 2$ & $m$ & $m$ & $m$ & $m$ & $m$ & $m$ \\
\hline$R I 3$ & $\mathrm{Y}$ & $\mathrm{Y}$ & $\mathrm{Y}$ & $\mathrm{Y}$ & $\mathrm{Y}$ & $\mathrm{Y}$ \\
\hline$R I 4$ & $\mathrm{Y}$ & $\mathrm{Y}$ & $\mathrm{Y}$ & $\mathrm{Y}$ & $\mathrm{Y}$ & $\mathrm{Y}$ \\
\hline$R I 5$ & $m$ & $\mathrm{Y}$ & $\mathrm{Y}$ & $\mathrm{Y}$ & $m$ & $m$ \\
\hline$R I 6$ & $\mathrm{Y}$ & $\mathrm{Y}$ & $\mathrm{Y}$ & $\mathrm{Y}$ & $\mathrm{Y}$ & $\mathrm{Y}$ \\
\hline$R R 1$ & $\mathrm{Y}$ & $\mathrm{Y}$ & $\mathrm{Y}$ & $\mathrm{Y}$ & $\mathrm{Y}$ & $\mathrm{Y}$ \\
\hline$R R 2$ & $\mathrm{Y}$ & $\mathrm{Y}$ & $\mathrm{Y}$ & $\mathrm{Y}$ & $\mathrm{Y}$ & $\mathrm{Y}$ \\
\hline$R R 3$ & $\mathrm{Y}$ & $\mathrm{Y}$ & $\mathrm{Y}$ & $\mathrm{Y}$ & $\mathrm{Y}$ & $\mathrm{Y}$ \\
\hline$R R 4$ & $\mathrm{Y}$ & $\mathrm{Y}$ & $\mathrm{Y}$ & $\mathrm{Y}$ & $\mathrm{Y}$ & $\mathrm{Y}$ \\
\hline$R R 5$ & $\mathrm{Y}$ & $\mathrm{Y}$ & $\mathrm{Y}$ & $\mathrm{Y}$ & $\mathrm{Y}$ & $\mathrm{Y}$ \\
\hline$R R 6$ & $\mathrm{Y}$ & $\mathrm{Y}$ & $\mathrm{Y}$ & $\mathrm{Y}$ & $\mathrm{Y}$ & $\mathrm{Y}$ \\
\hline$D M 1$ & $\mathrm{~N}$ & $\mathrm{Y}$ & $\mathrm{Y}$ & $\mathrm{Y}$ & $\mathrm{N}$ & $\mathrm{N}$ \\
\hline$D M 2$ & $\mathrm{~N}$ & $\mathrm{Y}$ & $\mathrm{Y}$ & $\mathrm{Y}$ & $m$ & $m$ \\
\hline$D M 3$ & $\mathrm{~N}$ & $\mathrm{Y}$ & $\mathrm{Y}$ & $\mathrm{Y}$ & $\mathrm{N}$ & $\mathrm{N}$ \\
\hline$D M 4$ & $\mathrm{~N}$ & $\mathrm{Y}$ & $\mathrm{Y}$ & $\mathrm{Y}$ & $\mathrm{N}$ & $\mathrm{N}$ \\
\hline$D M 5$ & $m$ & $\mathrm{Y}$ & $\mathrm{Y}$ & $\mathrm{Y}$ & $\mathrm{N}$ & $\mathrm{N}$ \\
\hline$D M 6$ & $m$ & $m$ & $m$ & $\mathrm{Y}$ & $\mathrm{Y}$ & $\mathrm{Y}$ \\
\hline$F P 1$ & $\mathrm{Y}$ & $\mathrm{Y}$ & $\mathrm{Y}$ & $\mathrm{Y}$ & $\mathrm{Y}$ & $\mathrm{Y}$ \\
\hline$F P 2$ & $\mathrm{Y}$ & $\mathrm{Y}$ & $\mathrm{Y}$ & $\mathrm{Y}$ & $m$ & $m$ \\
\hline$F P 3$ & $\mathrm{Y}$ & $\mathrm{Y}$ & $\mathrm{Y}$ & $\mathrm{Y}$ & $m$ & $m$ \\
\hline$F P 4$ & $\mathrm{Y}$ & $\mathrm{Y}$ & $\mathrm{Y}$ & $\mathrm{Y}$ & $\mathrm{Y}$ & $\mathrm{Y}$ \\
\hline$F P 5$ & $m$ & $m$ & $m$ & $m$ & $\mathrm{Y}$ & $\mathrm{Y}$ \\
\hline$F P 6$ & $m$ & $m$ & $m$ & $m$ & $\mathrm{~N}$ & $\mathrm{~N}$ \\
\hline
\end{tabular}

"Y" to influence favorably, "N" to not influence, and " $m$ " is unlikely to influence favorably.

\section{Step 4: Synthesize an internally consistent outcome space}

In this step, the different strategies to reduce the physical seismic risk in an urban area are shown. According to Table 2, those strategies can influence favorably, not influence or are unlikely to influence favorably, in each of the considered indicators of the physical seismic risk (from $X_{R P h 1}$ to $X_{R P h 6}$ ).

By way of example, the descriptor percentage of destroyed area $\left(X_{R P h 1}\right)$ would improve significantly if the 13 strategies (cells with "Y" key in dark grey in Table 2 and in Table 3 ) are executed: three related to risk identification $(R I 3, R I 4, R I 6)$; six to risk reduction ( $R R 1$ to $R R 6)$; and four to governance and financial protection (FP1 to FP4). 
Table 3. Strategies to reduce the Percentage of destroyed area, $\boldsymbol{X}_{\boldsymbol{R} \boldsymbol{P h} \mathbf{1}}$

\begin{tabular}{|c|c|c|c|c|c|c|c|c|c|}
\hline \multicolumn{2}{|c|}{$\begin{array}{c}\text { Descriptors of } \\
\text { physical damage }\end{array}$} & \multicolumn{2}{|c|}{ Risk identification } & \multirow{2}{*}{\multicolumn{2}{|c|}{$\begin{array}{l}\text { Risk reduction } \\
\text { Risk consideration in } \\
\text { land use and urban } \\
\text { planning }\end{array}$}} & \multicolumn{2}{|c|}{ Disaster management } & \multicolumn{2}{|r|}{$\begin{array}{l}\text { Governance and } \\
\text { financial protection }\end{array}$} \\
\hline$X_{R P h 1}$ & $\begin{array}{c}\text { Percentage of } \\
\text { destroyed } \\
\text { area }\end{array}$ & $R I 1$ & $\begin{array}{l}\text { Systematic } \\
\text { disaster and loss } \\
\text { inventory }\end{array}$ & & & $D M 1$ & $\begin{array}{l}\text { Organization and } \\
\text { coordination of } \\
\text { emergency } \\
\text { operations }\end{array}$ & $F P 1$ & $\begin{array}{l}\text { Inter-institutional, } \\
\text { multi-sectoral and } \\
\text { decentralizing } \\
\text { organization }\end{array}$ \\
\hline$X_{R P h 2}$ & Dead people & $R I 2$ & $\begin{array}{l}\text { Hazard } \\
\text { monitoring and } \\
\text { forecasting }\end{array}$ & $R R 2$ & $\begin{array}{l}\text { Hydrographical } \\
\text { basin intervention } \\
\text { and environmental } \\
\text { protection }\end{array}$ & $D M 2$ & $\begin{array}{l}\text { Emergency response } \\
\text { planning and } \\
\text { implementation of } \\
\text { warning systems }\end{array}$ & $F P 2$ & $\begin{array}{l}\text { Reserve funds for } \\
\text { institutional } \\
\text { strengthening }\end{array}$ \\
\hline$X_{R P h 3}$ & Injured & $R I 3$ & $\begin{array}{l}\text { Hazard } \\
\text { evaluation and } \\
\text { mapping }\end{array}$ & $R R 3$ & $\begin{array}{l}\text { Implementation of } \\
\text { hazard-event control } \\
\text { and protection } \\
\text { techniques }\end{array}$ & $D M 3$ & $\begin{array}{l}\text { Endowment of } \\
\text { equipment, tool, and } \\
\text { infrastructure }\end{array}$ & FP3 & $\begin{array}{l}\text { Budge } \\
\text { and } \mathrm{m}\end{array}$ \\
\hline$X_{R P h 4}$ & SS & RI4 & $\begin{array}{l}\text { Vulnerability } \\
\text { and risk } \\
\text { assessment }\end{array}$ & $R R 4$ & $\begin{array}{l}\text { Housing } \\
\text { improvement and } \\
\text { human settlement } \\
\text { relocation from } \\
\text { prone-areas }\end{array}$ & $D M 4$ & $\begin{array}{l}\text { Simulation, } \\
\text { updating, and test of } \\
\text { inter-institutional } \\
\text { response }\end{array}$ & FP4 & $\begin{array}{l}\text { Implementation of } \\
\text { social safety nets } \\
\text { and funds response }\end{array}$ \\
\hline$X_{R P h 5}$ & $\begin{array}{c}\text { Potential } \\
\text { damage in the } \\
\text { system of } \\
\text { potable water }\end{array}$ & $R I 5$ & $\begin{array}{l}\text { Public } \\
\text { information and } \\
\text { community } \\
\text { participation }\end{array}$ & $R R 5$ & $\begin{array}{l}\text { Updating and } \\
\text { enforcement of } \\
\text { safety standards and } \\
\text { construction codes }\end{array}$ & DM5 & $\begin{array}{l}\text { Community } \\
\text { preparedness and } \\
\text { training }\end{array}$ & FP5 & $\begin{array}{l}\text { Insurance coverage } \\
\text { and loss transfer } \\
\text { strategies of public } \\
\text { assets }\end{array}$ \\
\hline$X_{R P h 6}$ & $\begin{array}{l}\text { Damage for } \\
\text { the road } \\
\text { system }\end{array}$ & RI6 & $\begin{array}{l}\text { Training and } \\
\text { education on } \\
\text { risk } \\
\text { management }\end{array}$ & $R R 6$ & $\begin{array}{l}\text { Reinforcement and } \\
\text { retrofitting of public } \\
\text { and private assets }\end{array}$ & DM6 & $\begin{array}{l}\text { Rehabilitation and } \\
\text { reconstruction } \\
\text { planning }\end{array}$ & $F P 6$ & $\begin{array}{l}\text { Housing and private } \\
\text { sector insurance and } \\
\text { reinsurance } \\
\text { coverage }\end{array}$ \\
\hline
\end{tabular}

In the same way as the previous example, for the descriptor of the destroyed area, and according to the CCM (Table 2), strategies that would favorably influence the rest of the descriptors are provided below.

The contributing descriptors to population (dead people, $X_{R P h 2}$, and injured people, $\left.X_{R P h 3}\right)$ would decrease significantly if 19 strategies are executed: four related to risk identification ( $R I 3, R I 4, R I 5, R I 6)$; six to risk reduction ( $R R 1$ to $R R 6)$; five to disaster management (DM1 to DM5) and four to governance and financial protection (FP1 to FP4). See Table 4 with strategies for the $X_{R P h 2}$ descriptor.

The homeless descriptor $\left(X_{R P h 4}\right)$ would improve significantly if 20 strategies are executed: the 19 strategies that improve the dead people $\left(X_{R P h 2}\right)$ or injured people $\left(X_{R P h 3}\right)$ descriptors, and one strategy to disaster management (DM6) (see column $X_{R P h 4}$ in Table 2).

The contributing descriptors to physical damage of lifelines $\left(X_{R P h 5}\right.$ and $\left.X_{R P h 6}\right)$ would improve if 13 strategies are executed: three related to risk identification $(R I 3, R I 4, R I 6)$; six to risk reduction ( $R R 1$ and $R R 6)$; one to disaster management $(D M 6)$ and three to governance and financial protection $(F P 1, F P 4$ and FP5). Table 5 shows the strategies for the damage descriptor of the potable water system $\left(X_{R P h 5}\right)$. The descriptor damage for the road system $\left(X_{R P h 6}\right)$ requires the same strategies as the descriptor $X_{R P h 5}$. 
Table 4. Strategies to reduce the number of dead people, $\boldsymbol{X}_{\boldsymbol{R P h} \mathbf{2}}$

\begin{tabular}{|c|c|c|c|c|c|c|c|c|c|}
\hline \multicolumn{2}{|c|}{$\begin{array}{c}\text { Descriptors of physical } \\
\text { damage }\end{array}$} & \multicolumn{2}{|c|}{ Risk identification } & \multicolumn{2}{|r|}{ Risk reduction } & \multicolumn{2}{|c|}{ Disaster management } & \multicolumn{2}{|c|}{$\begin{array}{c}\text { Governance and } \\
\text { financial protection }\end{array}$} \\
\hline$X_{R P h 1}$ & $\begin{array}{c}\text { Percentage of } \\
\text { destroyed } \\
\text { area }\end{array}$ & $R I 1$ & $\begin{array}{l}\text { Systematic } \\
\text { disaster and } \\
\text { loss inventory }\end{array}$ & $R R 1$ & $\begin{array}{l}\text { Risk consideration } \\
\text { in land use and } \\
\text { urban planning }\end{array}$ & $D M 1$ & $\begin{array}{l}\text { Organization and } \\
\text { coordination of } \\
\text { emergency } \\
\text { operations }\end{array}$ & $F P 1$ & $\begin{array}{l}\text { Inter-institutional, } \\
\text { multisectoral and } \\
\text { decentralizing } \\
\text { organization }\end{array}$ \\
\hline$X_{R P h 2}$ & Dead people & $R I 2$ & $\begin{array}{l}\text { Hazard } \\
\text { monitoring and } \\
\text { forecasting }\end{array}$ & $R R 2$ & $\begin{array}{l}\text { Hydrographical } \\
\text { basin intervention } \\
\text { and environmental } \\
\text { protection }\end{array}$ & $D M 2$ & $\begin{array}{l}\text { Emergency } \\
\text { response planning } \\
\text { and implementation } \\
\text { of warning systems }\end{array}$ & FP2 & $\begin{array}{l}\text { Reserve funds for } \\
\text { institutional } \\
\text { strengthening }\end{array}$ \\
\hline$X_{R P h 3}$ & $\begin{array}{l}\text { Injured } \\
\text { people }\end{array}$ & $R I 3$ & $\begin{array}{l}\text { Hazard } \\
\text { evaluation and } \\
\text { mapping }\end{array}$ & $R R 3$ & $\begin{array}{l}\text { Implementation of } \\
\text { hazard-event } \\
\text { control and } \\
\text { protection } \\
\text { techniques }\end{array}$ & $D M 3$ & $\begin{array}{l}\text { Endowment of } \\
\text { equipment, tool, } \\
\text { and infrastructure }\end{array}$ & FP3 & $\begin{array}{l}\text { Budget allocation } \\
\text { and mobilization }\end{array}$ \\
\hline$X_{R P h 4}$ & Homeless & $R I 4$ & $\begin{array}{l}\text { Vulnerability } \\
\text { and risk } \\
\text { assessment }\end{array}$ & $R R 4$ & $\begin{array}{l}\text { Housing } \\
\text { improvement and } \\
\text { human settlement } \\
\text { relocation from } \\
\text { prone-areas }\end{array}$ & $D M 4$ & $\begin{array}{l}\text { Simulation, } \\
\text { updating, and test } \\
\text { of inter- } \\
\text { institutional } \\
\text { response }\end{array}$ & FP4 & $\begin{array}{l}\text { Implementation of } \\
\text { social safety nets } \\
\text { and funds response }\end{array}$ \\
\hline$X_{R P h 5}$ & $\begin{array}{c}\text { Potential } \\
\text { damage in } \\
\text { the system of } \\
\text { potable water }\end{array}$ & $R I 5$ & \begin{tabular}{|l} 
Public \\
information and \\
community \\
participation \\
\end{tabular} & $R R 5$ & $\begin{array}{l}\text { Updating and } \\
\text { enforcement of } \\
\text { safety standards and } \\
\text { construction codes } \\
\end{array}$ & $D M 5$ & $\begin{array}{l}\text { Community } \\
\text { preparedness and } \\
\text { training }\end{array}$ & FP5 & $\begin{array}{l}\text { Insurance coverage } \\
\text { and loss transfer } \\
\text { strategies of public } \\
\text { assets }\end{array}$ \\
\hline$X_{R P h 6}$ & $\begin{array}{c}\text { Damage for } \\
\text { the road } \\
\text { system }\end{array}$ & $R I 6$ & $\begin{array}{l}\text { Training and } \\
\text { education on } \\
\text { risk } \\
\text { management }\end{array}$ & $R R 6$ & $\begin{array}{l}\text { Reinforcement and } \\
\text { retrofitting of } \\
\text { public and private } \\
\text { assets }\end{array}$ & DM6 & $\begin{array}{l}\text { Rehabilitation and } \\
\text { reconstruction } \\
\text { planning }\end{array}$ & FP6 & $\begin{array}{l}\text { Housing and } \\
\text { private sector } \\
\text { insurance and } \\
\text { reinsurance } \\
\text { coverage }\end{array}$ \\
\hline
\end{tabular}

Table 5. Strategies to reduce the damage to the potable water system, $\boldsymbol{X}_{\boldsymbol{R P h} \mathbf{5}}$

\begin{tabular}{|c|c|c|c|c|c|c|c|c|c|}
\hline \multicolumn{2}{|c|}{$\begin{array}{c}\text { Descriptors of } \\
\text { physical damage }\end{array}$} & \multicolumn{2}{|c|}{ Risk identification } & \multicolumn{2}{|r|}{ Risk reduction } & \multicolumn{2}{|c|}{ Disaster management } & \multicolumn{2}{|c|}{$\begin{array}{c}\text { Governance and financial } \\
\text { protection }\end{array}$} \\
\hline$X_{R P h 1}$ & $\begin{array}{l}\text { Percentag } \\
\text { e of } \\
\text { destroyed } \\
\text { area }\end{array}$ & $R I 1$ & $\begin{array}{l}\text { Systematic } \\
\text { disaster and loss } \\
\text { inventory }\end{array}$ & $R R 1$ & $\begin{array}{l}\text { Risk consideration in } \\
\text { land use and urban } \\
\text { planning }\end{array}$ & $D M 1$ & $\begin{array}{l}\text { Organization and } \\
\text { coordination of } \\
\text { emergency operations }\end{array}$ & $F P 1$ & $\begin{array}{l}\text { Inter-institutional, } \\
\text { multi-sectoral and } \\
\text { decentralizing } \\
\text { organization }\end{array}$ \\
\hline$X_{R P h 2}$ & $\begin{array}{l}\text { Dead } \\
\text { people }\end{array}$ & $R I 2$ & $\begin{array}{l}\text { Hazard } \\
\text { monitoring and } \\
\text { forecasting }\end{array}$ & $R R 2$ & $\begin{array}{l}\text { Hydrographical } \\
\text { basin intervention } \\
\text { and environmental } \\
\text { protection }\end{array}$ & $D M 2$ & $\begin{array}{l}\text { Emergency response } \\
\text { planning and } \\
\text { implementation of } \\
\text { warning systems }\end{array}$ & $F P 2$ & $\begin{array}{l}\text { Reserve funds for } \\
\text { institutional } \\
\text { strengthening }\end{array}$ \\
\hline$X_{R P h 3}$ & $\begin{array}{l}\text { Injured } \\
\text { people }\end{array}$ & $R I 3$ & $\begin{array}{l}\text { Hazard } \\
\text { evaluation and } \\
\text { mapping }\end{array}$ & $R R 3$ & $\begin{array}{l}\text { Implementation of } \\
\text { hazard-event control } \\
\text { and protection } \\
\text { techniques }\end{array}$ & DM3 & $\begin{array}{l}\text { Endowment of } \\
\text { equipment, tool, and } \\
\text { infrastructure }\end{array}$ & FP3 & $\begin{array}{l}\text { Budget allocation } \\
\text { and mobilization }\end{array}$ \\
\hline$X_{R P h 4}$ & Homeless & $R I 4$ & $\begin{array}{l}\text { Vulnerability } \\
\text { and risk } \\
\text { assessment }\end{array}$ & $R R 4$ & $\begin{array}{l}\text { Housing } \\
\text { improvement and } \\
\text { human settlement } \\
\text { relocation from } \\
\text { prone-areas }\end{array}$ & $D M 4$ & $\begin{array}{l}\text { Simulation, updating, } \\
\text { and test of inter- } \\
\text { institutional response }\end{array}$ & FP4 & $\begin{array}{l}\text { Implementation of } \\
\text { social safety nets } \\
\text { and funds response }\end{array}$ \\
\hline$X_{R P h 5}$ & $\begin{array}{c}\text { Potential } \\
\text { damage in } \\
\text { the } \\
\text { potable } \\
\text { water } \\
\text { system }\end{array}$ & $R I 5$ & $\begin{array}{l}\text { Public } \\
\text { information and } \\
\text { community } \\
\text { participation }\end{array}$ & $R R 5$ & $\begin{array}{l}\text { Updating and } \\
\text { enforcement of } \\
\text { safety standards and } \\
\text { construction codes }\end{array}$ & DM5 & $\begin{array}{l}\text { Community } \\
\text { preparedness and } \\
\text { training }\end{array}$ & FP5 & $\begin{array}{l}\text { Insurance coverage } \\
\text { and loss transfer } \\
\text { strategies of public } \\
\text { assets }\end{array}$ \\
\hline$X_{R P h 6}$ & $\begin{array}{l}\text { Damage } \\
\text { for the } \\
\text { road } \\
\text { system }\end{array}$ & $R I 6$ & $\begin{array}{l}\text { Training and } \\
\text { education on } \\
\text { risk management }\end{array}$ & $R R 6$ & $\begin{array}{l}\text { Reinforcement and } \\
\text { retrofitting of public } \\
\text { and private assets }\end{array}$ & $D M 6$ & $\begin{array}{l}\text { Rehabilitation and } \\
\text { reconstruction } \\
\text { planning }\end{array}$ & FP6 & $\begin{array}{l}\text { Housing and private } \\
\text { sector insurance and } \\
\text { reinsurance } \\
\text { coverage }\end{array}$ \\
\hline
\end{tabular}


Finally, it is proposed that the action plans that help mitigate the seismic physical risk, according to the CCM (Table 2), are ranked based on the weighting of the contributing factors to the seismic physical risk in urban areas and the lower level of performance presented by the proposed strategies.

\subsection{Strategies to reduce the aggravating coefficient $(F)$}

To decrease the aggravating coefficient, the social context should be improved by reducing its social vulnerability. However, reach it can become a very complex task since society is a very flexible system with a high degree of uncertainty.

\subsubsection{Analysis Phase}

The morphological field proposed to select adequate strategies to decrease the aggravating coefficient involved 13 prevailing social indicators (Table 7) and 31 strategies (Table 6). These indicators and strategies are related to damages that not depend directly on the seismic event. Other indirect effects such as long-term physical and mental health impact, business disruptions and, education require diverse population-based samples and further research to obtain accurate and generalizable estimates [52,53].This study proposes 31 strategies grouped into five groups that will improve the social context and they contain different strategies expressed in actions to be followed. Some of them are the strategies proposed in the evaluation of the effectiveness of risk management [5], and others are new (code* and code respectively in Table 6). These five groups are:

- Evaluation of social context $(E)$. Those strategies allow the evaluation of different social aspects by analyzing the environment resources, and the necessities of the studied urban area. The evaluation is based on information provided by urban observers (UO) [55]; in case there are not observers, the relevant data collection must be made and then, a database should be created. This group involves five strategies.

- Training (T). It involves five strategies (Table 6) that allow social actors to be trained in different aspects that will reduce vulnerability. The development of group work skills such as communication, relationships, taking responsibility, decision-making, and conflict resolution, allow to understand the reality, to give an explanation and to be able to define de best change. In this way, the education strategies are defined for an urban area, according to the four pillars that should be the foundations for any educational 
vision [56]: "Learning to know, learning to do, learning to live together and learning to be". In this way citizen education is promoted for social transformation, and each person or group in the urban area is prepared for decision-making, self-management, coping with conflicts, solving individual and collective problems, and above all for the efficient and altruistic performance of their different social roles [24].

- Socio-Economic development (SE). This group has four strategies (Table 6). They include sets of activities, techniques, and procedures that can be carried out at different levels with the purpose of using and developing their resources and self-help in the search for solutions. These solutions have to adjust to the different conflicting socioeconomic situations existing in an urban area. The strategies of socio-economic development make it possible to take part, mediate or direct the individual, the family, and/or the community in the process of growth and development. These strategies make it easier for people the making of adaptive decisions in situations that affect them such as welfare, family planning, citizen participation, and the insurance of disasters losses in the housing and private sector.

- Physical Development (PD). It has six strategies (Table 6), which benefit immediately and directly to the urban area to intervene. These strategies promote the implementation of safety construction codes and protection techniques and a correct land and urban planning taking into account the potential risk in the area.

- Governance improvement $(G)$. It has eleven strategies (Table 6). They allow the interrelation of different social actors (which necessarily have different disciplinary approaches, values, and interests) to coordinate, execute and establish an adequate allocation and use of appropriate financial resources of retention and transfer of associated losses to disasters. Therefore, these strategies are fundamental for the sustainability of social development through the application of public policies for the governability of an urban area. 
Table 6. Strategies to reduce the aggravating coefficient $(\boldsymbol{F})$

\begin{tabular}{|c|c|c|c|}
\hline \multicolumn{2}{|r|}{ Strategies to reduce the aggravating coefficient $(F)$} & Code & Code* \\
\hline \multirow{5}{*}{$\begin{array}{l}\text { Group E: } \\
\text { Evaluation } \\
\text { of the social } \\
\text { context }\end{array}$} & $\begin{array}{l}\text { Identification of indicators of social vulnerability using databases (national } \\
\text { and/or regional statistic institute; Urban Observers -UO-). In case there are } \\
\text { no previous databases, the relevant data compilation must be made. }\end{array}$ & $E 1$ & \\
\hline & $\begin{array}{l}\text { Evaluation of the level of performance in the public policy of risk } \\
\text { identification }\end{array}$ & $E 2$ & \\
\hline & Evaluation of the level of performance in the public policy of risk reduction & $E 3$ & \\
\hline & $\begin{array}{l}\text { Evaluation of the level of performance in the public policy of disaster } \\
\text { management }\end{array}$ & $E 4$ & \\
\hline & $\begin{array}{l}\text { Evaluation of the level of performance in the public policy of governance } \\
\text { and financial protection }\end{array}$ & $E 5$ & \\
\hline \multirow{5}{*}{$\begin{array}{l}\text { Group T: } \\
\text { Training }\end{array}$} & Training and education on risk management & $T 1$ & $R I 6$ \\
\hline & Basic education & $T 2$ & \\
\hline & Training and education in technical-professional & T3 & \\
\hline & Public information and community & $T 4$ & $R I 5$ \\
\hline & Community preparedness and training & $T 5$ & DM5 \\
\hline \multirow{4}{*}{$\begin{array}{l}\text { Group SE: } \\
\text { Socio- } \\
\text { Economic } \\
\text { development }\end{array}$} & Promote social integration and support groups of disadvantaged people & $S E 1$ & \\
\hline & $\begin{array}{l}\text { Improve social participation, through public policies (existing or to be } \\
\text { developed) of citizen participation }\end{array}$ & $S E 2$ & \\
\hline & Family planning & SE3 & \\
\hline & Housing and private sector insurance and reinsurance coverage & SE4 & FP6 \\
\hline \multirow{6}{*}{$\begin{array}{l}\text { Group PD: } \\
\text { Physical } \\
\text { Development }\end{array}$} & Implementation of hazard-event control and protection techniques & $P D 1$ & $R R 3$ \\
\hline & Housing improvement and human settlement relocation from prone-areas & $P D 2$ & $R R 4$ \\
\hline & Updating and enforcement of safety standards and construction codes & $P D 3$ & $R R 5$ \\
\hline & Reinforcement and retrofitting of public and private assets & $P D 4$ & $R R 6$ \\
\hline & Risk consideration in land use and urban planning & $P D 5$ & $R R 1$ \\
\hline & Hydrographical basin intervention and environmental protection & PD6 & $R R 2$ \\
\hline \multirow{11}{*}{$\begin{array}{l}\text { Group G: } \\
\text { Governance } \\
\text { improvement }\end{array}$} & Organization and coordination of emergency operations & $G 1$ & $D M 1$ \\
\hline & Emergency response planning and implementation of warning systems & $G 2$ & $D M 2$ \\
\hline & Endowment of equipment, tool, and infrastructure & G3 & DM3 \\
\hline & Simulation, updating, and test of inter-institutional response & G4 & $D M 4$ \\
\hline & Rehabilitation and reconstruction planning & G5 & DM6 \\
\hline & Inter- institutional, multi-sectoral and decentralizing organization & G6 & $F P 1$ \\
\hline & Reserve funds for institutional strengthening & G7 & $F P 2$ \\
\hline & Budget allocation and mobilization & G8 & $F P 3$ \\
\hline & Implementation of social safety nets and funds response & G9 & FP4 \\
\hline & Insurance coverage and loss transfer strategies of public assets & $G 10$ & $F P 5$ \\
\hline & Improve the health system & G11 & \\
\hline
\end{tabular}

*Code based on [5] 
Table 7. Morphological field for reduction the aggravating coefficient $(\boldsymbol{F})$ of the urban area

\begin{tabular}{|c|c|c|c|c|c|c|c|c|c|c|c|}
\hline \multicolumn{2}{|c|}{ Social indicator } & \multicolumn{2}{|r|}{ Evaluation of social context } & \multicolumn{2}{|r|}{ Training } & \multicolumn{2}{|r|}{$\begin{array}{c}\text { Socio-economic } \\
\text { development }\end{array}$} & \multicolumn{2}{|c|}{ Physical development } & \multicolumn{2}{|r|}{$\begin{array}{c}\text { Governance } \\
\text { improvement }\end{array}$} \\
\hline$D w 1$ & Sufficient living area & $E 1$ & $\begin{array}{l}\text { Identification of indicators of social } \\
\text { vulnerability using databases } \\
\text { (national and/or regional statistic } \\
\text { institute; Urban Observers -UO-). In } \\
\text { case there are no previous databases, } \\
\text { the relevant, the relevant compilation } \\
\text { must be made and created }\end{array}$ & $T 1$ & $\begin{array}{l}\text { Training and } \\
\text { education on risk } \\
\text { management (RI6) }\end{array}$ & $S E 1$ & \begin{tabular}{|l|} 
Promote social \\
integration and support \\
groups of disadvantaged \\
people
\end{tabular} & $P D 1$ & $\begin{array}{l}\text { Implementation of } \\
\text { hazard-event control and } \\
\text { protection techniques }\end{array}$ & $G 1$ & $\begin{array}{l}\text { Organization and } \\
\text { coordination of } \\
\text { emergency operations }\end{array}$ \\
\hline$D w 2$ & State of dwelling & $E 2$ & $\begin{array}{l}\text { Evaluation of the level of } \\
\text { performance in the public policy of } \\
\text { risk identification }\end{array}$ & $T 2$ & Basic education. & $S E 2$ & $\begin{array}{|lr|}\text { Improve rocial } \\
\text { participation, through } \\
\text { public policies (existing } \\
\text { or to be developed) of } \\
\text { citizen participation } \\
\end{array}$ & $P D 2$ & $\begin{array}{l}\text { Housing improvement } \\
\text { and human settlement } \\
\text { relocation from prone- } \\
\text { areas }\end{array}$ & $G 2$ & \begin{tabular}{|lr} 
Emergency & response \\
planning & and \\
implementation & of \\
warning systems &
\end{tabular} \\
\hline$S D 5$ & Poor households & E3 & $\begin{array}{l}\text { Evaluation of the level of } \\
\text { performance in the public policy of } \\
\text { risk reduction }\end{array}$ & T3 & $\begin{array}{|lr|}\text { Training } & \text { and } \\
\text { education } & \text { in } \\
\text { technical- } & \\
\text { professional } & \\
\end{array}$ & $S E 3$ & Family planning & $P D 3$ & $\begin{array}{lrr}\text { Updating } & \text { and } \\
\text { enforcement of } & \text { safety } \\
\text { standards } & \text { and } \\
\text { construction codes } & \\
\end{array}$ & G3 & $\begin{array}{l}\text { Endowment } \\
\text { equipment, tool, and } \\
\text { infrastructure }\end{array}$ \\
\hline$S D 6$ & Literacy rate & $E 4$ & $\begin{array}{l}\text { Evaluation of the level of } \\
\text { performance in the public policy of } \\
\text { disaster management }\end{array}$ & $T 4$ & $\begin{array}{l}\text { Public information } \\
\text { and community } \\
\text { (RI5). }\end{array}$ & $S E 4$ & \begin{tabular}{|l|} 
Housing and private \\
sector insurance and \\
reinsurance coverage
\end{tabular} & $P D 4$ & $\begin{array}{l}\text { Reinforcement and } \\
\text { retrofitting of public and } \\
\text { private assets }\end{array}$ & $G 4$ & $\begin{array}{l}\text { Simulation, updating, } \\
\text { and test of inter- } \\
\text { institutional response }\end{array}$ \\
\hline$U P 1$ & $\begin{array}{l}\text { Growth of informal } \\
\text { settlements }\end{array}$ & $E 5$ & $\begin{array}{l}\text { Evaluation of the level of } \\
\text { performance in the public policy of } \\
\text { governance and financial protection }\end{array}$ & $T 5$ & $\begin{array}{l}\text { Community } \\
\text { preparedness and } \\
\text { training (DM5). }\end{array}$ & & & $P D 5$ & $\begin{array}{l}\text { Risk consideration in land } \\
\text { use and urban planning }\end{array}$ & G5 & $\begin{array}{l}\text { Rehabilitation and } \\
\text { reconstruction planning }\end{array}$ \\
\hline$U P 2$ & Level or urban planning & & & & & & & $P D 6$ & $\begin{array}{lr}\text { Hydrographical basin } \\
\text { intervention and } \\
\text { environmental protection }\end{array}$ & G6 & \begin{tabular}{|l|} 
Interinstitutional, \\
multisectoral and \\
decentralizing \\
organization \\
\end{tabular} \\
\hline$U P 3$ & $\begin{array}{l}\text { Homes built in risk-prone } \\
\text { areas }\end{array}$ & & & & & & & & & G7 & $\begin{array}{l}\text { Reserve funds for } \\
\text { institutional } \\
\text { strengthening }\end{array}$ \\
\hline$D R M i$ & $\begin{array}{l}\text { Disaster risk management } \\
\text { index, } D R M i\end{array}$ & & & & & & & & & $G 8$ & $\begin{array}{l}\text { Budget allocation and } \\
\text { mobilization }\end{array}$ \\
\hline$L R 1$ & Hospital beds & & & & & & & & & G9 & $\begin{array}{l}\text { Implementation of } \\
\text { social safety nets and } \\
\text { funds response }\end{array}$ \\
\hline$L R 2$ & Human resources in health & & & & & & & & & $G 10$ & $\begin{array}{l}\text { Insurance coverage and } \\
\text { loss transfer strategies of } \\
\text { public assets }\end{array}$ \\
\hline$L R 3$ & Relief personnel & & & & & & & & & $G 11$ & $\begin{array}{l}\text { Improve the health } \\
\text { system }\end{array}$ \\
\hline
\end{tabular}


According to [24] and [25], the aggravation coefficient, $F$, can be established by two different ways according to the available information of the case of study: a) General case $(\mathrm{n}=13)$, with 13 prevailing social indicators or $\mathrm{b})$ Simplified case by only six predominant indicators $(n=6)$, one for each category and higher level of determination. Therefore, these indicators are classified into six categories related to social aspects, in order of priority, they are Urban planning (C3), Governance (C4), Demography (C6), Dwelling (C1), Social development and poverty eradication (C2), and Lack of resilience (C5). In section 5 the application of the proposed methodology to evaluate the social context of the case of study (Mérida, Venezuela) will be was done, through the simplified case, due to the available information.

\subsubsection{Synthesis Phase}

Starting from the morphological field to reduce the aggravating coefficient or to improve the social context (Table 7) steps 3 and 4 are applied.

\section{Step 3: The Cross-Consistency Matrix (CCM) for the morphological field}

The CCM is setting by the relationship between the parameters of Table 8 using evaluation keys, to reduce the aggravating coefficient $(F)$. The evaluation matrix of crossconsistency adjusted in this study is shown in Table 8 . Where the strategies to decrease $F$ (classified by five groups) are in rows, and the contributing indicators to the social context are in columns. 
Table 8. The Cross-Consistency Matrix (CCM) to reduce the aggravating coefficient $(F)$ for an urban area

\begin{tabular}{|c|c|c|c|c|c|c|c|c|c|c|c|c|c|c|}
\hline \multirow{2}{*}{\multicolumn{2}{|c|}{ Strategies to reduce $F$}} & \multicolumn{13}{|c|}{ Indicators contributing to $F$} \\
\hline & & $D w 1$ & $D w 2$ & $S D 5$ & $S D 6$ & UP1 & \begin{tabular}{|l|l|}
$U P 2$ \\
\end{tabular} & $U P 3$ & $D R M i$ & $L R 1$ & $L R 2$ & $L R 3$ & $D 1$ & $D 2$ \\
\hline \multirow{5}{*}{$\begin{array}{l}\text { Evaluation of social } \\
\text { context }\end{array}$} & $E 1$ & $\mathrm{Y}$ & $\mathrm{Y}$ & $\mathrm{Y}$ & Y & $\mathrm{Y}$ & $\mathrm{Y}$ & $\mathrm{Y}$ & $\mathrm{Y}$ & $\bar{Y}$ & $\bar{Y}$ & $\mathrm{Y}$ & $\mathrm{Y}$ & $\mathrm{Y}$ \\
\hline & $E 2$ & $\mathrm{~N}$ & $\mathrm{~N}$ & $\mathrm{~N}$ & $\mathrm{~N}$ & $\mathrm{Y}$ & $\mathrm{Y}$ & $\mathrm{Y}$ & $\mathrm{Y}$ & $\mathrm{N}$ & $\mathrm{N}$ & $\mathrm{N}$ & $\mathrm{N}$ & $\mathrm{N}$ \\
\hline & $E 3$ & $\mathrm{~N}$ & $\mathrm{~N}$ & $\mathrm{~N}$ & $\mathrm{~N}$ & $\mathrm{Y}$ & $\bar{Y}$ & $\mathrm{Y}$ & $\bar{Y}$ & $\mathrm{~N}$ & $\mathrm{~N}$ & $\mathrm{~N}$ & $\mathrm{~N}$ & $\mathrm{~N}$ \\
\hline & $E 4$ & $\mathrm{~N}$ & $\mathrm{~N}$ & $\mathrm{~N}$ & $\mathrm{~N}$ & $\mathrm{~N}$ & $\mathrm{Y}$ & $\mathrm{Y}$ & $\mathrm{Y}$ & $\mathrm{Y}$ & $\mathrm{Y}$ & $\mathrm{Y}$ & $\mathrm{N}$ & $\mathrm{N}$ \\
\hline & $E 5$ & $\mathrm{~N}$ & $\mathrm{~N}$ & $\mathrm{~N}$ & $\mathrm{~N}$ & $\mathrm{~N}$ & $\mathrm{Y}$ & $\mathrm{Y}$ & $\mathrm{Y}$ & $\mathrm{N}$ & $\mathrm{N}$ & $\mathrm{N}$ & $\mathrm{N}$ & $\mathrm{N}$ \\
\hline \multirow{5}{*}{ Training } & $T 1$ & $\mathrm{Y}$ & $\mathrm{N}$ & $\mathrm{N}$ & $\mathrm{N}$ & Y & $\mathrm{N}$ & Y & Y & $\mathrm{N}$ & $\mathrm{N}$ & $\mathrm{N}$ & $\mathrm{N}$ & $\mathrm{N}$ \\
\hline & $T 2$ & $\mathrm{~N}$ & $\mathrm{~N}$ & $\bar{Y}$ & $\mathrm{Y}$ & $\mathrm{N}$ & $\mathrm{N}$ & $\mathrm{N}$ & $\mathrm{N}$ & $\mathrm{N}$ & $\mathrm{N}$ & $\mathrm{N}$ & $\mathrm{N}$ & $\mathrm{N}$ \\
\hline & T3 & $\mathrm{N}$ & $\mathrm{N}$ & $Y$ & $\mathrm{Y}$ & $\mathrm{N}$ & $\mathrm{N}$ & $\mathrm{N}$ & $\mathrm{N}$ & $\mathrm{N}$ & Y & Y & $\mathrm{N}$ & $\mathrm{N}$ \\
\hline & $T 4$ & $\mathrm{~N}$ & $\mathrm{~N}$ & $\mathrm{~N}$ & $\mathrm{~N}$ & $\mathrm{~N}$ & $\mathrm{~N}$ & $\mathrm{Y}$ & Y & $\mathrm{N}$ & $\mathrm{N}$ & $\mathrm{N}$ & $\mathrm{N}$ & $\mathrm{N}$ \\
\hline & $T 5$ & $\mathrm{~N}$ & $\mathrm{~N}$ & $\mathrm{~N}$ & $\mathrm{~N}$ & $\mathrm{~N}$ & $\mathrm{~N}$ & $\mathrm{Y}$ & $\mathrm{Y}$ & $\mathrm{N}$ & $\mathrm{N}$ & $\mathrm{N}$ & $\mathrm{N}$ & $\mathrm{N}$ \\
\hline \multirow{4}{*}{$\begin{array}{l}\text { Socio economic } \\
\text { development }\end{array}$} & $S E 1$ & $m$ & $\mathrm{Y}$ & $Y$ & $\mathrm{Y}$ & $\mathrm{Y}$ & $\mathrm{Y}$ & $\mathrm{Y}$ & $\mathrm{Y}$ & $\mathrm{N}$ & $\mathrm{N}$ & $\mathrm{N}$ & $\mathrm{N}$ & $\mathrm{N}$ \\
\hline & $S E 2$ & $m$ & $\mathrm{Y}$ & $\mathrm{Y}$ & $\mathrm{Y}$ & $\mathrm{Y}$ & $\mathrm{Y}$ & $\mathrm{Y}$ & Y & $\mathrm{N}$ & $\mathrm{N}$ & $\mathrm{N}$ & $\mathrm{N}$ & $\mathrm{N}$ \\
\hline & SE3 & $\mathrm{Y}$ & $\mathrm{N}$ & $\mathrm{Y}$ & $\mathrm{N}$ & $\mathrm{N}$ & $\mathrm{N}$ & $\mathrm{N}$ & $\mathrm{N}$ & $\mathrm{N}$ & $\mathrm{N}$ & $\mathrm{N}$ & $\mathrm{Y}$ & $\mathrm{Y}$ \\
\hline & $S E 4$ & $m$ & $\mathrm{~N}$ & $\mathrm{~N}$ & $\mathrm{~N}$ & $\mathrm{~N}$ & $\mathrm{Y}$ & $\mathrm{N}$ & $Y$ & $\mathrm{~N}$ & $\mathrm{~N}$ & $\mathrm{~N}$ & $\mathrm{~N}$ & $\mathrm{~N}$ \\
\hline \multirow{6}{*}{ Physical development } & $P D 1$ & $m$ & $\mathrm{~N}$ & $\mathrm{~N}$ & $\mathrm{~N}$ & $\mathrm{Y}$ & $\mathrm{Y}$ & $\mathrm{Y}$ & $\mathrm{Y}$ & $\mathrm{N}$ & $\mathrm{N}$ & $\mathrm{N}$ & $\mathrm{N}$ & $\mathrm{N}$ \\
\hline & $P D 2$ & $\mathrm{Y}$ & $\mathrm{Y}$ & $\mathrm{N}$ & $\mathrm{N}$ & $\mathrm{Y}$ & $\mathrm{Y}$ & $\mathrm{Y}$ & $\bar{Y}$ & $\mathrm{~N}$ & $\mathrm{~N}$ & $\mathrm{~N}$ & $\mathrm{Y}$ & $\mathrm{N}$ \\
\hline & PD3 & $m$ & $\mathrm{Y}$ & $\mathrm{N}$ & $\mathrm{N}$ & $m$ & $\mathrm{Y}$ & $\mathrm{N}$ & $\mathrm{Y}$ & $\mathrm{N}$ & $\mathrm{N}$ & $\mathrm{N}$ & $\mathrm{N}$ & $\mathrm{N}$ \\
\hline & $P D 4$ & $\mathrm{~N}$ & $\mathrm{Y}$ & $\mathrm{N}$ & $\mathrm{N}$ & $\mathrm{N}$ & $\mathrm{Y}$ & $\mathrm{N}$ & $\mathrm{Y}$ & $\mathrm{Y}$ & $\mathrm{N}$ & $\mathrm{N}$ & $\mathrm{N}$ & $\mathrm{N}$ \\
\hline & $P D 5$ & $m$ & $\mathrm{~N}$ & $\mathrm{~N}$ & $\mathrm{~N}$ & $m$ & $\mathrm{Y}$ & $\mathrm{Y}$ & Y & $\mathrm{N}$ & $\mathrm{N}$ & $\mathrm{N}$ & $\mathrm{N}$ & $\mathrm{N}$ \\
\hline & $P D 6$ & $\mathrm{~N}$ & $\mathrm{~N}$ & $\mathrm{~N}$ & $\mathrm{~N}$ & $\mathrm{~N}$ & Y & $\mathrm{Y}$ & $\mathrm{Y}$ & $\mathrm{N}$ & $\mathrm{N}$ & $\mathrm{N}$ & $\mathrm{N}$ & $\mathrm{N}$ \\
\hline \multirow{11}{*}{$\begin{array}{l}\text { Governance } \\
\text { improvement }\end{array}$} & $G 1$ & $\mathrm{~N}$ & $\mathrm{~N}$ & $\mathrm{~N}$ & $\mathrm{~N}$ & $\mathrm{~N}$ & $\mathrm{~N}$ & $\mathrm{~N}$ & $\mathrm{Y}$ & $\mathrm{N}$ & $\mathrm{N}$ & $\mathrm{Y}$ & $\mathrm{N}$ & $\mathrm{N}$ \\
\hline & $G 2$ & $\mathrm{~N}$ & $\mathrm{~N}$ & $\mathrm{~N}$ & $\mathrm{~N}$ & $\mathrm{~N}$ & $\mathrm{~N}$ & $\mathrm{~N}$ & $\mathrm{Y}$ & $\mathrm{N}$ & $\mathrm{Y}$ & $\mathrm{Y}$ & $\mathrm{N}$ & $\mathrm{N}$ \\
\hline & G3 & $\mathrm{N}$ & $\mathrm{N}$ & $\mathrm{N}$ & $\mathrm{N}$ & $\mathrm{N}$ & $\mathrm{N}$ & $\mathrm{N}$ & $\mathrm{Y}$ & $\mathrm{Y}$ & $Y$ & $\mathrm{Y}$ & $\mathrm{N}$ & $\mathrm{N}$ \\
\hline & $G 4$ & $\mathrm{~N}$ & $\mathrm{~N}$ & $\mathrm{~N}$ & $\mathrm{~N}$ & $\mathrm{~N}$ & $\mathrm{~N}$ & $\mathrm{~N}$ & Y & $\mathrm{N}$ & $\mathrm{N}$ & $\mathrm{N}$ & $\mathrm{N}$ & $\mathrm{N}$ \\
\hline & $G 5$ & $\mathrm{~N}$ & $m$ & $\mathrm{~N}$ & $\mathrm{~N}$ & $\mathrm{~N}$ & $\mathrm{~N}$ & $\mathrm{~N}$ & Y & $\mathrm{N}$ & $\mathrm{N}$ & $\mathrm{N}$ & $\mathrm{N}$ & $\mathrm{N}$ \\
\hline & $G 6$ & $\mathrm{Y}$ & $\mathrm{Y}$ & $\mathrm{N}$ & $\mathrm{N}$ & $\mathrm{Y}$ & $\mathrm{Y}$ & $\mathrm{Y}$ & $\mathrm{Y}$ & $\mathrm{N}$ & $\mathrm{N}$ & $\mathrm{N}$ & $\mathrm{N}$ & $\mathrm{N}$ \\
\hline & $G 7$ & $\mathrm{~N}$ & $\mathrm{~N}$ & $\mathrm{~N}$ & $\mathrm{~N}$ & $\mathrm{~N}$ & $\mathrm{~N}$ & $\mathrm{~N}$ & Y & $\mathrm{N}$ & $\mathrm{N}$ & $\mathrm{N}$ & $\mathrm{N}$ & $\mathrm{N}$ \\
\hline & G8 & $\mathrm{N}$ & $\mathrm{N}$ & $\mathrm{N}$ & $\mathrm{N}$ & $\mathrm{N}$ & $\mathrm{N}$ & $\mathrm{N}$ & $\mathrm{Y}$ & $\mathrm{N}$ & $\mathrm{N}$ & $\mathrm{N}$ & $\mathrm{N}$ & $\mathrm{N}$ \\
\hline & G9 & $m$ & $\mathrm{Y}$ & $\mathrm{Y}$ & $\mathrm{N}$ & $\mathrm{N}$ & $\mathrm{N}$ & $\mathrm{Y}$ & $\mathrm{Y}$ & $\mathrm{N}$ & $\mathrm{N}$ & $\mathrm{N}$ & $\mathrm{N}$ & $\mathrm{N}$ \\
\hline & $G 10$ & $\mathrm{~N}$ & $\mathrm{~N}$ & $\mathrm{~N}$ & $\mathrm{~N}$ & $\mathrm{~N}$ & Y & $\mathrm{N}$ & Y & $\mathrm{N}$ & $\mathrm{N}$ & $\mathrm{N}$ & $\mathrm{N}$ & $\mathrm{N}$ \\
\hline & $G 11$ & $\mathrm{~N}$ & $\mathrm{~N}$ & $\mathrm{~N}$ & $\mathrm{~N}$ & $\mathrm{~N}$ & $\mathrm{~N}$ & $\mathrm{~N}$ & $\mathrm{Y}$ & $\mathrm{Y}$ & $\mathrm{Y}$ & $\mathrm{Y}$ & $\mathrm{N}$ & $\mathrm{N}$ \\
\hline
\end{tabular}

"Y" to influence favorably, "N" to not influence, and " $m$ " is unlikely to influence favorable.

\section{Step 4: Synthesize an internally consistent outcome space}

As an example, the resulting strategies of the proposed morphological field to improve the social indicator growth of informal settlements (UP1), related to urban planning category $(C 3)$, are detailed. It describes the annual growth of the population in urban agglomeration or urban areas without planning self-constructed by the inhabitants 
thereof (spontaneous marginal neighborhoods). UP1 is estimated by the proportion of self-built houses compared to regulated dwellings. Specifically, there are nine strategies that influence favorably to improve the social indicator UP1 (dark grey cells in Table 8 and Table 9). The CCM (Table 8) proposes to implement the following strategies:

- Group E. Evaluation of the context.

Identification of indicators of social vulnerability, $E 1$, using existing databases (national and/or regional statistic institute; Urban Observers -UO-) or collecting relevant information. Evaluation of the level of performance in the public policy of risk identification, E2, and Evaluation of the level of performance in the public policy of risk reduction, $E 3$.

- Group T. Training.

Training and education on risk management, $T 1$.

- Group SE. Socio-Economic development.

Promote social integration and support groups of disadvantaged people, SE1, and Improve social participation, $S E 2$, through public policies (existing or to be developed) of citizen participation.

- Group PD. Physical Development.

Implementation of hazard-event control and protection techniques, PD1, and Housing improvement and human settlement relocation from prone-areas, $P D 2$.

- Group G. Governance improvement.

Inter-institutional, multi-sectoral and decentralizing organization, G6.

Additionally, it is possible to apply the strategies that are unlikely to influence favorably on UP1 (cells in light grey in Table 8), which are: Updating and enforcement of safety standards and construction codes, $P D 3$, and Risk consideration in land use and urban planning, $P D 5$.

To establish the action plans or strategies to improve each of the other social indicators proposed in Table 7, it is required to proceed in the same way as the example shown for the $U P 1$ indicator.

As a result of the morphological analysis, from the 31 proposed strategies to reduce the aggravating coefficient, 21 help to improve at least three social indicators, 16 to improve at least four social indicators and only six strategies help to improve at least six (Table 8). Finally, the following priority criteria are recommended: i) to implement 
the strategies that help simultaneously to reduce the aggravating coefficient among the six social indicators prevailing, and ii) the strategies that help simultaneously to improve at least three social indicators. 
Table 9. Strategies proposed to improve the social indicator UP1 (dark gray cells)

\begin{tabular}{|c|c|c|c|c|c|c|c|c|c|c|c|}
\hline \multicolumn{2}{|c|}{ Social indicator } & \multirow{2}{*}{\multicolumn{2}{|c|}{\begin{tabular}{|l|} 
Evaluation of social context \\
\multirow{2}{*}{$E 1$} \\
$\begin{array}{l}\text { Identification of indicators of social } \\
\text { vulnerability using databases } \\
\text { (national and/or regional statistic } \\
\text { institute; Urban Observers -UO-). In } \\
\text { case there are no previous databases, } \\
\text { the relevant, the relevant } \\
\text { compilation must be made and } \\
\text { created }\end{array}$
\end{tabular}}} & \multicolumn{2}{|r|}{ Training } & \multicolumn{2}{|c|}{ Socio-economic development } & \multicolumn{2}{|r|}{ Physical development } & \multicolumn{2}{|r|}{ Governance improvement } \\
\hline$D w 1$ & \begin{tabular}{|l|} 
Sufficient \\
area
\end{tabular} & & & $T 1$ & $\begin{array}{l}\text { Training and education } \\
\text { on risk management } \\
\text { (RI6) }\end{array}$ & $S E 1$ & $\begin{array}{l}\text { Promote social integration } \\
\text { and support groups of } \\
\text { disadvantaged people }\end{array}$ & PD1 & $\begin{array}{l}\text { Implementation of hazard-event } \\
\text { control and protection } \\
\text { techniques }\end{array}$ & $G 1$ & $\begin{array}{l}\text { Organization and coordination of } \\
\text { emergency operations }\end{array}$ \\
\hline$D w 2$ & State of dwelling & $E 2$ & $\begin{array}{l}\text { Evaluation of the level of } \\
\text { performance in the public policy of } \\
\text { risk identification (RI) }\end{array}$ & $T 2$ & Basic education. & $S E 2$ & $\begin{array}{l}\text { Improve social participation, } \\
\text { through public policies } \\
\text { (existing or to be developed) } \\
\text { of citizen participation }\end{array}$ & PD2 & $\begin{array}{l}\text { Housing improvement and } \\
\text { human settlement relocation } \\
\text { from prone-areas }\end{array}$ & $G 2$ & $\begin{array}{l}\text { Emergency response planning } \\
\text { and implementation of warning } \\
\text { systems }\end{array}$ \\
\hline$S D 5$ & Poor households & E3 & $\begin{array}{l}\text { Evaluation of the level of } \\
\text { performance in the public policy of } \\
\text { risk reduction (RR) }\end{array}$ & $T 3$ & $\begin{array}{l}\text { Training and education } \\
\text { in technical- } \\
\text { professional }\end{array}$ & $S E 3$ & Family planning & PD3 & $\begin{array}{l}\text { Updating and enforcement of } \\
\text { safety standards and } \\
\text { construction codes }\end{array}$ & G3 & $\begin{array}{l}\text { Endowment of equipment, tool, } \\
\text { and infrastructure }\end{array}$ \\
\hline$S D 6$ & Literacy rate & $E 4$ & $\begin{array}{l}\text { Evaluation of the level of } \\
\text { performance in the public policy of } \\
\text { disaster management (DM) }\end{array}$ & $T 4$ & $\begin{array}{l}\text { Public information and } \\
\text { community (RI5). }\end{array}$ & SE4 & $\begin{array}{l}\text { Housing and private sector } \\
\text { insurance and reinsurance } \\
\text { coverage }\end{array}$ & PD4 & $\begin{array}{l}\text { Reinforcement and retrofitting } \\
\text { of public and private assets }\end{array}$ & G4 & $\begin{array}{l}\text { Simulation, updating, and test of } \\
\text { inter-institutional response }\end{array}$ \\
\hline$U P 1$ & $\begin{array}{l}\text { Growth of informal } \\
\text { settlements }\end{array}$ & $E 5$ & $\begin{array}{l}\text { Evaluation of the level of } \\
\text { performance in the public policy of } \\
\text { governance and financial protection } \\
\text { (PF) }\end{array}$ & $T 5$ & \begin{tabular}{|l|} 
Community \\
preparedness \\
training (DM5).
\end{tabular} & & & PD5 & $\begin{array}{l}\text { Risk consideration in land use } \\
\text { and urban planning }\end{array}$ & G5 & $\begin{array}{l}\text { Rehabilitation and reconstruction } \\
\text { planning }\end{array}$ \\
\hline$U P 2$ & \begin{tabular}{|l}
$\begin{array}{l}\text { Level or urban } \\
\text { planning }\end{array}$ \\
\end{tabular} & & & & & & & PD6 & $\begin{array}{|lr|}\text { Hydrographical basin } \\
\text { intervention and environmental } \\
\text { protection }\end{array}$ & G6 & $\begin{array}{l}\text { Interinstitutional, multisectoral } \\
\text { and decentralizing organization }\end{array}$ \\
\hline UP3 & $\begin{array}{l}\text { Homes built in risk- } \\
\text { prone areas }\end{array}$ & & & & & & & & & G7 & $\begin{array}{l}\text { Reserve funds for institutional } \\
\text { strengthening }\end{array}$ \\
\hline$D R M i$ & $\begin{array}{|lr|}\text { Disaster risk } & \text { riser } \\
\text { management } & \text { index, } \\
D R M i & \\
\end{array}$ & & & & & & & & & G8 & $\begin{array}{l}\text { Budget allocation and } \\
\text { mobilization }\end{array}$ \\
\hline$L R 1$ & Hospital beds & & & & & & & & & $G 9$ & $\begin{array}{l}\text { Implementation of social safety } \\
\text { nets and funds response }\end{array}$ \\
\hline$L R 2$ & $\begin{array}{l}\text { Human resources in } \\
\text { health }\end{array}$ & & & & & & & & & $G 10$ & $\begin{array}{l}\text { Insurance coverage and loss } \\
\text { transfer strategies of public assets }\end{array}$ \\
\hline$L R 3$ & Relief personnel & & & & & & & & & $G 11$ & Improve the health system \\
\hline
\end{tabular}




\section{Application example for Mérida, Venezuela}

The proposed methodology based on a morphological analysis to support the formulation of action plans for disaster risk mitigation has been applied to Mérida city (Venezuela). It takes as a starting point a previous holistic and quantitative evaluation the seismic risk in this city [25].

\subsection{Holistic evaluation for the city of Mérida}

The city of Mérida is located in the Nort-Est of Venezuela, in the central part of the Venezuela Andes. It is on a plateau or long terrace within a floodplain (Quaternary sediments), bounded by two mountain ranges: the Sierra Nevada in South-East and the Sierra de la Culata in North-West and crossed by the Albarregas and Chama rivers [57,58].

Merida, with a total population of fewer than 250 thousand inhabitants is the capital of both the state of Merida and the Libertador municipality. The city is made up of 12 of the 15 parishes of the municipality: Arias, Milla, Osuna Rodríguez, Juan Rodríguez Suárez, Jacinto Plaza Lasso de Vega, Caracciolo Parra Pérez, Mariano Picón Salas and Antonio Spinetti Dini, El Llano, Sagrario and Domingo Peña [59,60,61]. Merida is located within an area of high seismic activity (zone 4 and 5 according to the seismic classification of structural normative in Venezuela, which divides the country into seven zones with different seismic hazard [62]. Below the city runs the major tectonic fault in western Venezuela The Boconó fault, which forms part of the South American Plate [63]. The Mérida city could be affected by several natural hazards, as the seismic hazard $[25,64]$.

The performance level of the indicators involved in the Disaster Risk Management Index, $D R M i$, was evaluated by individual interviews to six renowned local experts belonging to academia, non-governmental organization and local government of Mérida , carried out by one of the authors. The weights for the indicators in each public policy $(R R, D M, F P$, see Figure 1) were also assigned according to the local experts' criteria. The DRMi was evaluated was for years 2000, 2005 and 2010, but in this article, only the evaluation for 2010 is used.

The results obtained for the $D R M i$ evaluation are summarized as follows. In general, the public administration of Merida presents a significant level of performance 
with low effectiveness $(D R M i=34.55)$. This administration has focused more the efforts in the risk identification (an outstanding level with medium effectiveness, $R M I_{R I}=50.6$ ), and less in the financial protection and governance $\left(R M I_{P F}=13.28\right)$ level incipient to low with low effectiveness). The performance of the risk reduction $\left(R M I_{R R}=37.18\right)$ and disaster management activities $\left(R M I_{D M}=37.12\right)$ have a significant level, but with low effectiveness. Figure 5 shows the performance levels of the 24 indicators evaluated by the $D R M i$ for 2010, where it highlights about half of these indicators have a performance level lower than significant.

\subsection{Results of the general case}

According to the analyses of the Cross-Consistency Matrices of Table 2 and Table 8 , only 22 of the 24 indicators (strategies) involved in the $D R M i$, have favorably influence to reduce the physical risk and the aggravating coefficient. Therefore, to improve the social vulnerability and reduce the physical seismic risk in Merida, each of these strategies have to increase a considerable number of levels (between two and four) to reach an optimal level of performance (value 5).

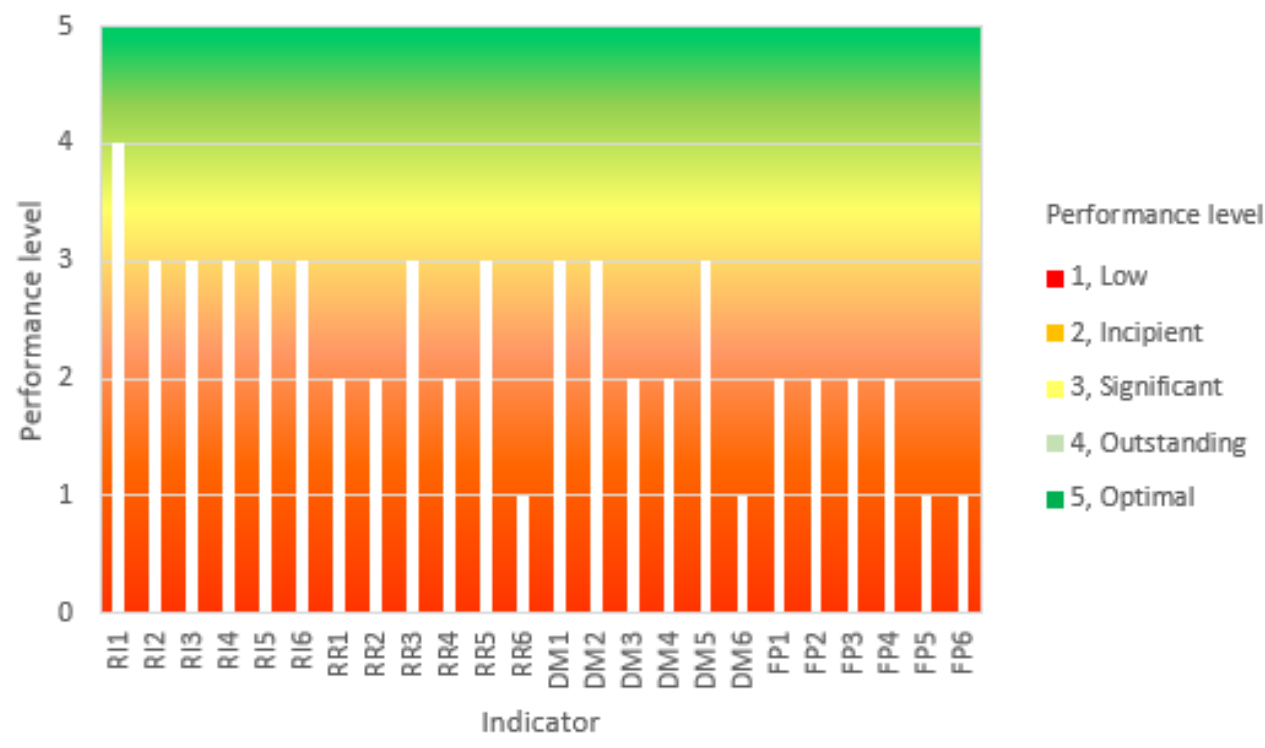

Figure 5. Performance Level (low, incipient, significant, outstanding, and optimal) for the 24 strategies to reduce the seismic risk in Mérida (Venezuela) in 2010.

The seismic risk for Merida was recently evaluated from a holistic approach involving scenarios of intensity VII and IX, and it includes 11 of the 12 parishes of the 
city [25]. These results for intensity IX are combined with the evaluation of the $D R M i$ in the application of the proposed methodology.

The morphological analysis suggested to implement strategies according to the following priority criteria: $i$ ) those to reduce the destroyed area according to Table 3 ; ii) the strategies to reduce the affectation to the population (dead, injured and the homeless) according to Tables 2 and 4; iii) those to mitigate the damage on lifelines. In the case of Merida, the last one refers to the potential damage in the system of a potable water (XRF4) and damage to the road system $(X R F 5)$. According to Table 2, 11 strategies have a favorable influence on all indicators of physical risk. All of them should be promoted in each parish of the city.

According to Jaramillo et al. [25], the parishes with high physical seismic risk are Antonio Spinetti Dini, Caracciolo Parra Pérez, and Osuna Rodríguez. The parishes with very high risk correspond to Arias, Domingo Peña, El Llano, Milla, and Sagrario. For both cases, it is imperative to apply the 13 strategies, which allow reducing the destroyed area, according to the column $X R F 1$ of the CCM in Table 2. These strategies are three of risk identification $(R I 3, R I 4, R I 6)$, six strategies of risk reduction, and four strategies of governance and financial protection (FP1 to FP4).

For parishes with a high or very high estimated physical seismic risk, 20 strategies are proposed to reduce the homeless descriptor: the 13 strategies that allow reducing the destroyed area descriptor $X F R 1$, and the six strategies related to public policies of disaster management (from DM1 to DM6) and the strategy RI5. Finally, to reduce the descriptors of dead and injured people, to execute 19 strategies: the same that allow reducing the homeless people, except the DM6 (see column XFR4 in Table 2).

The physical seismic risk associated with the potential damage to the potable water system is high for all parishes of the city [25]. In order to reduce it, 13 strategies are proposed to be implemented: three strategies of risk identification (RI3, RI4, RI6), six strategies of risk reduction (from $R R 1$ to $R R 6$ ); one strategy related to disaster management (DM6) and three strategies of governance and financial protection (FP1, FP4 and FP5). The promotion of these 13 strategies is particularly important in parishes where the maximum contributing factor to physical seismic risk for intensity IX was the damage of the potable water system: Juan Rodríguez Suárez, Lasso de la Vega and Mariano Picón Salas [25]. 
The priority areas to reduce the physical seismic risk for the city of Merida are the following parishes: i) Sagrario, Domingo Peña, Milla, El Llano, and Arias, due to their very high level of seismic risk $\left(R_{P h}\right)$; ii) parishes with a high level of seismic risk: Osuna Rodríguez, Antonio Spinetti Dini and Caracciolo Parra Pérez.

\subsection{Results of the Simplified case}

Furthermore, the evaluation of the social context in the parishes of the city was done, through the simplified case of the methodology. That means, with one indicator by category [25] due to the available information and the simplified estimation of the aggravating coefficient $F$.

The six categories sorted by priority are (see their corresponding weights participation, Wi, in Table 10): Urban planning (C3), Governance (C4), Demography (C6), Dwelling (C1), Social development and poverty eradication (C2), and Lack of resilience $(C 5)$. The six prevailing social indicators sorted in the same way are Level or

urban planning (UP2), Disaster risk management index (DRMi), Population density (D1), Sufficient living area (Dw1), Poor households (SD5), and Hospital beds (LR1). 
Table 10. The Cross-Consistency Matrix (CCM) for reduction of the aggravating coefficient $(F)$ for the city of Mérida.

\begin{tabular}{|c|c|c|c|c|c|c|c|}
\hline \multirow{2}{*}{\multicolumn{2}{|c|}{\begin{tabular}{|l} 
Strategies to decrease \\
$F$
\end{tabular}}} & \multicolumn{6}{|c|}{$\begin{array}{l}\text { Category } \\
\text { (Weights participation of the contributing factors to the aggravating } \\
\text { coefficient,[25]) }\end{array}$} \\
\hline & & $\begin{array}{c}C 1 \\
(0.168)\end{array}$ & $\begin{array}{c}C 2 \\
(0.123)\end{array}$ & $\begin{array}{c}C 3 \\
(0.224)\end{array}$ & $\begin{array}{c}C 4 \\
(0.220)\end{array}$ & $\begin{array}{c}C 5 \\
(0.088)\end{array}$ & $\begin{array}{c}C 6 \\
(0.177)\end{array}$ \\
\hline & & \multicolumn{6}{|c|}{ Indicators contributing to $F$ for the case: Mérida, Venezuela } \\
\hline & & $D w 1$ & $S D 5$ & $U P 2$ & $D R M i$ & $L R 1$ & $D 1$ \\
\hline \multirow{5}{*}{$\begin{array}{l}\text { Group E: } \\
\text { Evaluation of } \\
\text { social context }\end{array}$} & $E 1$ & Y & Y & $\mathrm{Y}$ & $\mathrm{Y}$ & Y & $\mathrm{Y}$ \\
\hline & $E 2$ & $\mathrm{~N}$ & $\mathrm{~N}$ & Y & Y & $\mathrm{N}$ & $\mathrm{N}$ \\
\hline & E3 & $\mathrm{N}$ & $\mathrm{N}$ & Y & Y & $\mathrm{N}$ & $\mathrm{N}$ \\
\hline & E4 & $\mathrm{N}$ & $\mathrm{N}$ & Y & $\mathrm{Y}$ & Y & $\mathrm{N}$ \\
\hline & E5 & $\mathrm{N}$ & $\mathrm{N}$ & Y & $\mathrm{Y}$ & $\mathrm{N}$ & $\mathrm{N}$ \\
\hline \multirow{5}{*}{$\begin{array}{l}\text { Group T: } \\
\text { Training }\end{array}$} & $T 1$ & Y & $\mathrm{N}$ & $\mathrm{N}$ & Y & $\mathrm{N}$ & $\mathrm{N}$ \\
\hline & $T 2$ & $\mathrm{~N}$ & $\mathrm{Y}$ & $\mathrm{N}$ & $\mathrm{N}$ & $\mathrm{N}$ & $\mathrm{N}$ \\
\hline & T3 & $\mathrm{N}$ & Y & $\mathrm{N}$ & $\mathrm{N}$ & $\mathrm{N}$ & $\mathrm{N}$ \\
\hline & $T 4$ & $\mathrm{~N}$ & $\mathrm{~N}$ & $\mathrm{~N}$ & Y & $\mathrm{N}$ & $\mathrm{N}$ \\
\hline & T5 & $\mathrm{N}$ & $\mathrm{N}$ & $\mathrm{N}$ & Y & $\mathrm{N}$ & $\mathrm{N}$ \\
\hline \multirow{4}{*}{$\begin{array}{l}\text { Group SE: } \\
\text { Socio- } \\
\text { Economic } \\
\text { development }\end{array}$} & $S E 1$ & $m$ & $\mathrm{Y}$ & $\mathrm{Y}$ & $\mathrm{Y}$ & $\mathrm{N}$ & $\mathrm{N}$ \\
\hline & $S E 2$ & $m$ & Y & Y & Y & $\mathrm{N}$ & $\mathrm{N}$ \\
\hline & $S E 3$ & Y & Y & $\mathrm{N}$ & $\mathrm{N}$ & $\mathrm{N}$ & Y \\
\hline & SE4 & $m$ & $\mathrm{~N}$ & Y & Y & $\mathrm{N}$ & $\mathrm{N}$ \\
\hline \multirow{6}{*}{$\begin{array}{l}\text { Group PD: } \\
\text { Physical } \\
\text { Development }\end{array}$} & $P D 1$ & $m$ & $\mathrm{~N}$ & Y & $\mathrm{Y}$ & $\mathrm{N}$ & $\mathrm{N}$ \\
\hline & $P D 2$ & $\mathrm{Y}$ & $\mathrm{N}$ & $\mathrm{Y}$ & $\mathrm{Y}$ & $\mathrm{N}$ & Y \\
\hline & PD3 & $m$ & $\mathrm{~N}$ & $\mathrm{Y}$ & Y & $\mathrm{N}$ & $\mathrm{N}$ \\
\hline & $P D 4$ & $\mathrm{~N}$ & $\mathrm{~N}$ & Y & Y & Y & $\mathrm{N}$ \\
\hline & $P D 5$ & $m$ & $\mathrm{~N}$ & Y & Y & $\mathrm{N}$ & $\mathrm{N}$ \\
\hline & PD6 & $\mathrm{N}$ & $\mathrm{N}$ & Y & $\mathrm{Y}$ & $\mathrm{N}$ & $\mathrm{N}$ \\
\hline \multirow{11}{*}{$\begin{array}{l}\text { Group G: } \\
\text { Governance } \\
\text { improvement }\end{array}$} & $G 1$ & $\mathrm{~N}$ & $\mathrm{~N}$ & $\mathrm{~N}$ & Y & $\mathrm{N}$ & $\mathrm{N}$ \\
\hline & $G 2$ & $\mathrm{~N}$ & $\mathrm{~N}$ & $\mathrm{~N}$ & $\mathrm{Y}$ & $\mathrm{N}$ & $\mathrm{N}$ \\
\hline & G3 & $\mathrm{N}$ & $\mathrm{N}$ & $\mathrm{N}$ & $\mathrm{Y}$ & Y & $\mathrm{N}$ \\
\hline & $G 4$ & $\mathrm{~N}$ & $\mathrm{~N}$ & $\mathrm{~N}$ & Y & $\mathrm{N}$ & $\mathrm{N}$ \\
\hline & $G 5$ & $\mathrm{~N}$ & $\mathrm{~N}$ & $\mathrm{~N}$ & $\mathrm{Y}$ & $\mathrm{N}$ & $\mathrm{N}$ \\
\hline & G6 & Y & $\mathrm{N}$ & Y & $\mathrm{Y}$ & $\mathrm{N}$ & $\mathrm{N}$ \\
\hline & G7 & $\mathrm{N}$ & $\mathrm{N}$ & $\mathrm{N}$ & $\mathrm{Y}$ & $\mathrm{N}$ & $\mathrm{N}$ \\
\hline & G8 & $\mathrm{N}$ & $\mathrm{N}$ & $\mathrm{N}$ & $\mathrm{Y}$ & $\mathrm{N}$ & $\mathrm{N}$ \\
\hline & $G 9$ & $m$ & Y & $\mathrm{N}$ & Y & $\mathrm{N}$ & $\mathrm{N}$ \\
\hline & $G 10$ & $\mathrm{~N}$ & $\mathrm{~N}$ & Y & $\mathrm{Y}$ & $\mathrm{N}$ & $\mathrm{N}$ \\
\hline & $G 11$ & $\mathrm{~N}$ & $\mathrm{~N}$ & $\mathrm{~N}$ & Y & Y & $\mathrm{N}$ \\
\hline
\end{tabular}

For the case of study, from the 31 proposed strategies to reduce the aggravating coefficient, 21 help to improve at least two social indicators and only eight strategies help to improve at least three social indicators (Table 8 or Table 10). 
The proposed criterion to execute the strategies for the city of Mérida is first the Identification of indicators of social vulnerability $(E 1)$. Then, the strategies which improve at least three indicators: Evaluation of the disaster management (E4), Promote social integration and support groups of disadvantaged people (SE1), Improve social participation (SE2), Family planning (SE3), Housing improvement and human settlement relocation from prone-areas (PD2), Reinforcement and retrofitting of public and private assets (PD4) and finally Inter-institutional, multi-sectoral and decentralizing organization (G6).

In summary, the decision-makers of the local governments should focus their efforts to implement the strategies related to risk reduction and some strategies of governance and financial protection, to reach an optimal level of performance in them all.

Specifically, the strategies suggested to improve the indicator with the highest weight Level of urban planning (UP2) (Table 10) are listed below:

- Group E. Evaluation of the context: all the strategies.

- Group SE. Socio-Economic development: Promote social integration and support groups of disadvantaged people ( $S E 1)$, Improve social participation, through public policies (existing or to be developed) of citizen participation (SE2) and Housing and private sector insurance and reinsurance coverage (SE4).

- Group PD. Physical Development: all the strategies.

- Group G. Improve the governance: Inter-institutional, multi-sectoral and decentralizing organization $(G 6)$ and Insurance coverage, and loss transfer strategies of public assets (G10).

\section{Conclusion}

This article proposes a methodology to support the decision-making process in the risk reduction of an urban area. It is based on a morphological analysis which involves: i) the results of a holistic evaluation of the disaster risk due to natural hazards, and ii) 35 strategies to reduce the physical risk and the aggravating social conditions of the urban area. 
Morphological analysis has been applied in different areas of research, but none of them integrating a holistic risk assessment due to natural hazards with the purpose of helping public stakeholders in the decision making process at a local level, for urban areas.

To reduce the physical risk, the proposed methodology involved 24 strategies, which correspond to the indicators evaluated by the Disaster Risk Management index, $D R M i$. These strategies are related to four public policies for disaster risk management: risk identification, risk reduction, disaster management, and governance and financial protection.

To reduce the aggravating conditions, which means to improve the social context, 31 strategies are identified to be applied. These strategies are related to: $i$ ) the evaluation of the social context; ii) training, iii) socio-economic development; iv) physical development, and v) governance improvement. The involved strategies are prioritized considering the weights of the factors related to the physical risk and the performance level according to the $D R M i$ evaluation (Figure 5).

The methodology has been applied to the city of Merida, Venezuela, where 11 potential strategies have been identified to reduce the potential physical damage and aggravating conditions. These strategies have a positive influence on at least six indicators. They, sorted by priority, are:

First, Reinforcement and retrofitting of public and private assets strategy $(P D 4 / R R 6)$ because it has a low-performance level and helps to reduce the seismic physical risk $R_{P h}$ as well as the aggravating coefficient $F$. It has a positive influence on nine indicators including the destroyed area $X_{R P h 1}$.

Then, strategies with an incipient performance level which have influence on all indicators of physical risk and at least two indicators of the aggravating conditions. They are: risk consideration in land use and urban planning $(P D 5 / R R 1)$; hydrographical basin intervention and environmental protection ( $P D 6 / R R 2)$; housing improvement and human settlement relocation from prone-areas ( $P D 2 / R R 4)$, inter-institutional, multisectorial and decentralizing organization $(G 6 / F P 1)$ and implementation of social safety nets and funds response (G9/FP4).

The following strategies have a significant performance level and influence on all indicators of physical risk and at least on two indicators of the aggravating conditions: training and education on risk management (RI6), implementation of hazard-event 
control and protection techniques $(P D 1 / R R 3)$ and the updating and enforcement of safety standards and construction codes (PD3/RR5). Additionally, the strategies hazard evaluation and mapping (RI3) and vulnerability and risk assessment (RI4) influence all physical risk indicators.

The methodology proposed in this study is easy to adapt to different urban areas and for whatever natural hazard using as parameters: the proposed actions and the possible damages to reduce. It could be better to evaluate the performance of disaster risk management through the $D R M i$, also a holistic evaluation of risk. The obtained results from this methodology could be applied by decision-makers and administrators as a guide to implementing effective risk mitigation strategies.

\section{Acknowledgments}

The authors express their gratitude for the support of the Ministry of Economy, Industry, and Competitiveness of Spain "Evaluación de la Vulnerabilidad y el Riesgo de Zonas Urbanas Expuestas a Amenazas Naturales y Antrópicas” (BIA2016-78544-R). We acknowledge the financial support to CIMNE via the CERCA Programme / Generalitat de Catalunya.

\section{References}

[1] ATC-13 (1985). Earthquake damage evaluation data for California, ATC-13. Redwook City, California: Applied Technology Council. 492.

[2] FEMA (1999). Earthquake loss estimation methodology. HAZUS-99 Technical manual. Federal Emergency Management Agency. Washington, D.C.

[3] RADIUS (2000). Risk Assessment tools for DIagnosis of Urban areas against Seismic Disasters. Available at: https://www.geohaz.org/risk-assessment-tools-for-diagnosis-of-u. [Accessed April 2019].

[4] Mouroux P., Brun B.L. (2006). Risk-Ue Project: An Advanced Approach to Earthquake Risk Scenarios With Application to Different European Towns. In C. S. Oliveira, A. Roca, \& X. Goula, Assessing and Managing Earthquake Risk. Geo-scientific and Engineering Knowledge for Earthquake Risk Mitigation: developments, tools, techniques, Vol. 2, 479-508.

[5] Carreño M.L., Cardona O.D., Barbat A.H. (2007). Urban seismic risk evaluation: a holistic approach. NAT HAZARDS 40 (1), 137-172.

[6] Cardona O.D., Ordaz M., Yamin L., Barbat A.H. (2011). Enfoque integral para la evaluación probabilista del riesgo (CAPRA): Iniciativa internacional para la efectividad de la gestión del riesgo de desastre. $4^{\circ}$ Congreso Nacional de Ingeniería Sísmica (4CNIS). Granada, Spain.

[7] Birkmann J. (2006). Measuring Vulnerability to Natural Hazards: Towards disaster resilient societies. Tokyo, Japan: United Nations University, Institute for Environment and Human Security, UNUEHS. 
[8] Birkmann J., Cardona O.D., Carreño M.L., Barbat A.H., Pelling M., Schneiderbauer S., Welle T. (2013). Framing vulnerability, risk and societal responses: the MOVE framework. NAT HAZARDS, 67, 193-211.

[9] Cardona O.D. (2001). Estimación holística del riesgo sísmico utilizando sistemas dinámicos complejos. Doctoral thesis, Universitat Politècnica de Catalunya, Barcelona, Spain (in Spanish)

[10] Cutter S. (1996). Vulnerability to environmental hazard. PROG HUM GEOG, 20 (4), 529539 .

[11] De Oliveira M.J. (2009). Social vulnerability indexes as planning tools: beyond the preparedness paradigm. J RISK RES, 12 (1), 43-58.

[12] Roberts N.J., Nadim F., Kalsnes B. (2009). Quantification of vulnerability to natural hazards. Georisk: Assessment and Management of Risk for Engineered Systems and Geohazards, 3 (3), 164-173. DOI: 10.1080/17499510902788850.

[13] Villagrán De León J.C. (2006). Vulnerability A Conceptual and Methodological Review. Bonn, Germany: United Nations University, Institute for Environment and Human Security, UNU-EHS. No 4.

[14] Silva V., Crowley H., Pagani M., Monelli D., Pinho R. (2014). Development of the Open Quake engine, the Global Earthquake Model's open-source software for seismic risk assessment. NAT HAZARDS 72(3), 1409-1427, doi:10.1007/ s11069-013-0618-x.

[15] Mattei A., Fiasca F, Mazzei M, Necozione S and Bianchini V (2017). Stress and Burnout in Health-Care Workers after the 2009 L'Aquila Earthquake: A Cross-Sectional Observational Study. FRONT. PSYCHIATRY 8:98. doi: 10.3389/fpsyt.2017.00098

[16] Miki T, Fujiwara T, Yagi J, Homma H, Mashiko H, Nagao K and Okuyama M (2019) Impact of Parenting Style on Clinically Significant Behavioral Problems Among Children Aged 4-11 Years Old After Disaster: A Follow-Up Study of the Great East Japan Earthquake. FRONT. PSYCHIATRY 10:45. doi: 10.3389/fpsyt.2019.00045

[17] Yu K.D.S., Tan R.R., Aviso K.B., Promentilla M.A.B., Santos J.R. (2014). A vulnerability index for post-disaster key sector prioritization. ECON SYST RES 26(1): 81-97. DOI: $10.1080 / 09535314.2013 .872603$

[18] Arto I., Andreoni V., Rueda Cantuche J.M. (2015). Global Impacts of the Automotive Supply Chain Disruption Following the Japanese Earthquake of 2011. ECON SYST RES 27(3): 306-323. https://doi.org/10.1080/09535314.2015.1034657

[19] Bellagamba X., Bradley B.A., Wotherspoon L.M, and Lagrava W.D. (2019) A DecisionSupport Algorithm for Post-Earthquake Water Services Recovery and Its Application to the 22 February $2011 \mathrm{Mw} 6.2$ Christchurch Earthquake. EARTHQ SPECTRA, August 2019, Vol. 35, No. 3, pp. 1397-1420. https://doi.org/10.1193/052218EQS119M

[20] Coar M., Garlock M. and Khorasani N.E. (2019) Effects of water network dependency on electric network for post-earthquake fire suppression. Journal of Sustainable and resilient Infrastructure. https://doi.org/10.1080/23789689.2018.1563408

[21] Hassan EM, Mahmoud H (2019) Full functionality and recovery assessment framework for a hospital subjected to a scenario earthquake event. ENG STRUCT, 188:165-177. DOI: $\quad 10.1016 /$ j.engstruct.2019.03.008 https://rd.springer.com/article/10.1007/s11069-0173089-7. [Accessed September 2019]. 
[22] Carreño M.L., Cardona O.D., Barbat A.H. (2012). New methodology for urban seismic risk assessment from a holistic perspective. B EARTHQ ENG 10(2), 547-565.

[23] Carreño M.L., Barbat A.H., Cardona O.D. (2014). Método numérico para la evaluación holística del riesgo sísmico utilizando la teoría de conjuntos difusos. Revista Internacional de Métodos Numéricos para Cálculo y Diseño en Ingeniería 3, 25-34.

[24] Jaramillo N. (2014). Evaluación holística del riesgo sísmico en zonas urbanas y estrategias para su mitigación. Aplicación a la ciudad de Mérida-Venezuela. Doctoral thesis, Universitat Politècnica de Catalunya, Barcelona, Spain (in Spanish).

[25] Jaramillo N., Carreño M.L., Lantada N. (2016). Evaluation of social context integrated into the study of seismic risk for urban areas. INT J DISAST RISK RE 17, 185-198.

[26] Hernández M.L., Carreño M.L., Castillo L. (2018). Methodologies and tools of risk management: Hurricane risk index (HRi). INT J DISAST RISK RE 31: 926-937

[27 Carreño M.L., Cardona O.D., Barbat A.H. (2007). A disaster risk management performance index. NAT HAZARDS 41(1), 1-20.

[28] Pigeon P., Rebotier J., (2016), Disaster Prevention Policies. A Challenging and Critical Outlook, London, ISTE Press - Elsevier.

[29] Nyimbili, P.H. and Erden, T. (2018) Spatial decision support systems (SDSS) and software applications for earthquake disaster management with special reference to Turkey NAT HAZARDS Volume 90, Issue 3, pp 1485-1507. https://doi.org/10.1007/s11069-017-3089-7

[30] Gregory R., Hailing L., Harstone M., Long G., McDaniels T. and Ohlson D. (2012) Structured Decision Making: A Practical Guide to Environmental Management. John Wiley \& Sons. ISBN978-1-4443-3341-1

[31] Ritchey T. (2011). Modelling Alternative Futures with General Morphological Analysis, World Future Review, Spring 2011. pp. 83-94. Available at: http://www.swemorph.com/pdf/wfrritchey.pdf . [Accessed August 2019].

[32] de Fatima M and Freire J. (2017) A general Morphological Analysis to support strategic management decisions in public transport. TRANSP RES PROC 22 509-518

[33] Habitat Agenda (1996). United Nations Conference on Human Settlements (Habitat II) in Istanbul, Turkey from 3 to 14 June 1996. Available at: http://www.un-documents.net/hab-ag.htm. [Accessed August 2019].

[34 Istanbul+5 (2001). Istanbul+5: United Nations Centre for Human Settlements (Habitat). General Assembly, Special Session for an overall review \& appraisal of the implementation of the Habitat Agenda. New York, 6-8 June 2001. Available at: http://www.un.org/ga/Istanbul+5/. [Accessed August 2019].

[35] MDGs (2008). The Millennium Development Goals Report. Department of Economic and Social Affairs of the United Nations Secretariat. Available at: http://www.un.org/millenniumgoals/2008highlevel/pdf/newsroom/mdg\%20reports/MDG_Repo rt 2008 ENGLISH.pdf. [Accessed August 2019].

[36] Saaty T.L. (1980). The Analytic Hierarchy Process. New York: McGraw-Hill

[37] Carreño M.L. (2006). Técnicas innovadoras para la evaluación del riesgo sísmico y su gestión en centros urbanos: Acciones ex ante y ex post. Doctoral Thesis, Universitat Politècnica de Catalunya, Barcelona, Spain (in Spanish). 
[38] Carreño M.L., Cardona O.D., Barbat A.H. (2017). Measuring Resilience Using a Comprehensive Approach to Assess Disaster Risk Management Performance. $2^{\text {nd }}$ International Workshop on Modelling of Physical, Economic and Social Systems for Resilience Assessment. Ispra, Italy, December 14-16 2017.

[39] Khazai B., Bendimerad F., Cardona O.D., Carreño M.L., Barbat A.H., Burton C.G. (2015). A guide to measuring urban risk resilience: Principles, tools and practice of urban indicators. Quezon, Philippines: Earthquake Megacities Initiative. Available at: https://www.preventionweb.net/publications/view/43439. [Accessed September 2019].

[40] Cardona O.D. (2003). La noción del riesgo desde la perspectiva de los desastres: Marco conceptual para su gestión integral. Manizales-Colombia: Instituto de estudios ambientales (IDEA-BID) (in Spanish).

[41] UNISDR (2004). Living with risk: a global review of disaster reduction initiatives. United Nations Office for Disaster Risk Reduction (UNISDR). ISBN/ISSN: 9211010640. https://www.unisdr.org/we/inform/publications/657. [Accessed September 2019].

[42] Asamblea Nacional (2009). Ley de gestión integral de riesgos socio-naturales y tecnológicos. Gaceta Oficial No 39.095. 9 de enero de 2009. Asamblea Nacional de la República Bolivariana de Venezuela (in Spanish).

[43] Pitilakis K., Crowley H., Kaynia A.M. (2014). SYNER-G: Typology Definition and Fragility Functions for Physical Elements at Seismic Risk, Springer, GEOT GEOL EARTHQUAKE, 27, ISBN: 978-94- 007-7871-9 (Print), 978-94-007-7872-6 (Online).

[44] Ritchey T. (2011). General Morphological Analysis A general method for non-quantified modelling. Adapted from the paper "Fritz Zwicky, Morphologie and Policy Analysis", presented at the $16^{\text {th }}$ EURO Conference on Operational Analysis, Brussels, 1998. Available at http://www.swemorph.com/pdf/gma.pdf. [Accessed September 2019].

[45] Zwicky F. (1969). Discovery, Invention, Research Through the Morphological Approach. Toronto: The Macmillan Company.

[46] Ritchey T. (2003). Nuclear Facilities and Sabotage: Using Morphological Analysis as a Scenario and Strategy Development Laboratory. Adaptation of a Paper delivered to the $44^{\text {th }}$ Annual Meeting of the Institute of Nuclear Materials Management - PhoeniN, Arizona, July 2003. Available at: www.swemorph.com. [Accessed September 2019].

[47] Ritchey T. (2015). Principles of Cross-Consistency Assessment in General Morphological Modelling. Acta Morphologica Generalis (AMG). Vol. 4 No. 2. Swedish Morphological Society. ISSN 2001-2241

[48] Ritchey T. (2006). Modeling Multi-Hazard Disaster Reduction Strategies with ComputerAided Morphological Analysis. Reprint from the Proceedings of the $3^{\text {rd }}$ International ISCRAM Conference, Newark, NJ (USA). Available at http://www.swemorph.com/pdf/multi.pdf. [Accessed September 2019].

[49] Álvarez A., Ritchey T. (2015). Applications of General Morphological Analysis from Engineering Design to Policy Analysis. Acta Morphologica Generalis (AMG). Vol. 4 No. 1 ISSN 2001-2241

[50] Johansen I. (2018). Scenario modelling with morphological. Technological Forecasting \& Social Change 126 (2018), 116-125

[51] Voros J. (2018). On a morphology of contact scenario space. Technological Forecasting \& Social Change 126 (2018), 126-137 
[52] Honda Y., Fujiwara T., Yagi, J., Homma H., Mashiko H., Nagao K., Okuyama M., OnoKihara M., Kihara M. (2019). Long-Term Impact of Parental Post-Traumatic Stress Disorder Symptoms on Mental Health of Their Offspring After the Great East Japan Earthquake. FRONT PSYCHIATRY 10: 496. DOI: 10.3389/fpsyt.2019.00496

[53] Adebäck P., Schulman A., Nilsson D. (2017). Children exposed to a natural disaster: psychological consequences eight years after 2004 tsunami. NORD J PSYCHIAT 72(1): 75-81. https://doi.org/10.1080/08039488.2017.1382569

[54] HAZUS' 99 (2002) Technical Manual Earthquake Loss Estimation Methodology, HAZUS99-SR2, developed by the Federal Emergency Managing Agency, FEMA and National Institute of Building Sciences, NIBS. Vol. 1-3. Washington, D.C., USA.

[55] UN-HABITAT (2015) A Guide to Setting up an Urban Observatory. Available at https://unhabitat.org/a-guide-to-setting-up-an-urban-observatory_2015/. [Accessed February 2019].

[56] Delors J., Al Mufti I., Amagi I., Carneiro R., Chung F., Geremek B., Gorham W., Kornhauser A., Manley M., Padrón Quero M., Savané M.A., Singh K., Stavenhagen R., Won Suhr M., Nanzhao Z. (1996). Learning: The Treasure Within. Report to UNESCO of the International Commission on Education for the Twenty-First Century. Paris: UNESCO. ISBN:923-103274-7. Available at: http://www.unesco.org/education/pdf/15 62.pdf. [Accessed September 2019].

[57] MOP (1976). Microzonificación sísmica de la meseta de Mérida (Vol. I y II). Caracas, Venezuela: Publicaciones Técnicas, Ministerio de Obras Públicas, Dirección General de Desarrollo Urbanístico, Secretaría Técnica (Venezuela), (in Spanish).

[58] Gutiérrez J. (2008). Actualización del mapa geológico del área metropolitana de MéridaVenezuela. The $33^{\text {rd }}$ IGC International Geological Congress, Oslo, Norway. 6-14 August 2008.

[59] Rebotier J. (2006). Método de localización de los heridos en el caso de un terremoto en la ciudad de Mérida, Venezuela. Revista Geográfica Venezolana 47, 187-200 (in Spanish).

[60] Castillo A. (2005). Seismic risk scenarios for buildings in Merida, Venezuela. Detailed vulnerability assessment for non-engineered housing. Doctoral thesis, Universitat Politècnica de Catalunya, Barcelona, Spain. Available at: http://hdl.handle.net/10803/6537. [Accessed April 2019].

[61] Alcaldía de Mérida (2002). Gaceta Municipal. Mérida. Depósito Legal Nro. 79-0151 Extraordinaria Nro.58 Año III: Consejo Municipal. Municipio Libertador (in Spanish).

[62] COVENIN (2001). Edificaciones Sismorresistentes. Norma COVENIN 1756:2.001. Venezuela, (in Spanish).

[63] Funvisis (2000). Mapa de fallas cuaternarias de Venezuela. Available at:

http://www.funvisis.gob.ve/old/archivos/mapas/fallas_activas.pdf. [Accessed September 2019].

[64] Castillo A., López-Almansa F., Pujades L.G. (2011). Seismic risk analysis of urban nonengineered buildings: application to an informal settlement in Merida, Venezuela. NAT. HAZARDS 59, 891-916, Doi: http://dx.doi.org/10.1007/ 